\title{
Uranium in Africa
}

\author{
Judith A. Kinnaird and Paul A.M. Nex \\ EGRI, School of Geosciences, University of the Witwatersrand.E-mail: Judith.kinnaird@wits.ac.za
}

DOI: 10.18814/epiiugs/2016/v39i2/95782

\begin{abstract}
Africa has been a significant world producer of uranium since 1945 when it was discovered in the DRC (then the Belgian Congo). There are four major types of deposits that produce the majority of the uranium in Africa: the Archaean quartz-conglomerate hosted golduranium deposits of South Africa; the Neoproterozoic end-orogeny sheeted leucogranites and small stocks of Namibia; the Mesozoic sandstone-hosted roll-front deposits of Niger and Malawi; and the recent channelhosted calcrete and alluvial deposits in Namibia. Primary deposits are regarded in this text as those where mines extract uranium as the main, or sole commodity, whereas secondary deposits such as the Witwatersrand Basin, produce another commodity as the prime metal with uranium as a by-product.
\end{abstract}

\section{Introduction}

Uranium is a silvery grey metal that was first discovered in 1789 and its earliest use was as a colouring agent in glass and ceramics. In 1898 Marie Curie discovered two decay products of uranium; radium and polonium and used them for therapeutic purposes, then in World War 1, X-rays were used in the medical field. The discovery of nuclear fission in 1939 led to the development of nuclear reactors in 1943. Worldwide in 2014 there were 434 operating nuclear reactors. These provide about $11 \%$ of the world's electricity, with some countries such as France, heavily reliant on nuclear energy. In spite of a slowdown in nuclear reactor development following the tsunamiinduced Fukushima accident, demand for uranium is forecast to increase as there are 71 reactors currently under construction, mainly in China, Russia, India, S. Korea and the United States, while 173 are planned that are likely to be operational within 10 years. According to the World Nuclear Association, this growing market can be provided by a rising supply from current mines, but by 2025-2030, new mines will be needed. Currently, Kazakhstan (25\%), Canada (13\%) and Australia (9\%), supply almost $50 \%$ of the current world supply with Africa contributing $~ 18 \%$.

There are several commercial ores of uranium including uraninite, coffinite, carnotite, montroseite, autunite, boltwoodite and uranophane/betauranophane, with other ores including brannerite, betafite, uranothorite and davidite, locally forming accessories that are not so amenable to conventional acid leaching. The typical composition of these minerals is shown in Table 1.

In 2005 , the uranium price rose steadily from below US\$ 20 a pound (lb) to mid-2007 when the spot price briefly reached
US\$ $140 \mathrm{a} \mathrm{lb}$. The increasing price led to extensive uranium exploration across the continent but by the beginning of 2010 as the price fell to US $\$ 40 \mathrm{alb}$, many of these projects were abandoned due to the low price of the commodity. This resulted in 2014 in the Kayelekera Mine in Malawi being placed on care and maintenance, the delay of development at the Trekkopje Mine in Namibia (projected to produce 5 million pounds (mlbs) of triuranium octoxide $\left(\mathrm{U}_{3} \mathrm{O}_{8}\right)$ by 2020), the Ryst Kuil deposit in South Africa and the Bakouma deposit in the central Africa Republic, whilst production has slowed at the Langer Heinrich and Rössing Mines in Namibia. There is the potential for uranium production in several other African countries when the price rises above 80 US $\$$ lb. In 2013, Africa produced around 10,500 tonnes of uranium from Niger, Namibia, Malawi and South Africa. The announcement in early 2015, that China plans to resume their nuclear programme means that the outlook for uranium must improve. Uranium is used almost entirely for the generation of electricity, with a small amount used for medical isotopes.

\section{Historical development of uranium production in Africa}

Africa has been a significant world producer of uranium since the 1920s following the discovery in 1915 in DRC (then the Belgian Congo) at Shinkolobwe, $25 \mathrm{~km}$ west of Likasi in Katanga, by Union Minière du Haut Katanga. The Société Générale Métallurgique de Hokoben began extracting uranium which was used for the medical treatment of certain cancers. Following a brief closure in 1937, Shinkolobwe was reopened and the United States government purchased around 3,000 tonnes of uranium (tU) for the Manhattan Project in the early 1940s. About 25,000 tU was produced over the subsequent two decades from this vein-hosted deposit, but production ceased on independence in 1960, when the shafts were sealed and guarded. The deposit has been unofficially mined since 1997 for cobalt, although a United Nations report in 2004 prompted concerns that some uranium from Shinkolobwe might be contributing to illicit weapons programs in some countries. In 2009, Areva signed a uranium exploration agreement for Katanga with the government, focused on Shinkolobwe, but has since said that it will not embark on any plans for mining in the near future and there is no current mining or exploration for uranium in the country.

Granite-hosted uranium mineralisation in Namibia was first noted in the early 1920s by the occurrence of the mineral davidite in the vicinity of Rössing Mountain (Jacob, 1974b). Rio Tinto discovered numerous uranium occurrences and in 1966 took the rights over the low-grade Rössing deposit, $65 \mathrm{~km}$ inland from Swakopmund, and a mine has been in operation there since 1976. Two other significant deposits found in early exploration in Namibia were Trekkopje, a calcrete-hosted deposit $80 \mathrm{~km}$ northeast of Swakopmund, and Langer 
Table 1. Generalised compositional data for uranium minerals (based on formulae given by Mindat.org) and associated minerals, their typical occurrence and approximate uranium content

\begin{tabular}{|c|c|c|c|}
\hline Mineral & Typical Formula & Occurrence & $\%$ uranium \\
\hline $\begin{array}{l}\text { Autunite/meta- } \\
\text { autunite }\end{array}$ & $\mathrm{Ca}\left(\mathrm{UO}_{2}\right)_{2}\left(\mathrm{PO}_{4}\right)_{2} \cdot 11 \mathrm{H}_{2} \mathrm{O}$ & $\begin{array}{l}\text { In the oxidation zone of uranium bearing rocks, including } \\
\text { sandstones, hydrothermal veins, and granitic pegmatites }\end{array}$ & 57 \\
\hline Betafite & $\begin{array}{l}(\mathrm{Ca}, \mathrm{Na}, \mathrm{U}, \mathrm{REE})_{16-\mathrm{x}}(\mathrm{Nb}, \mathrm{Ti})_{16} \mathrm{O}_{48} \\
(\mathrm{O}, \mathrm{OH}, \mathrm{F})_{8-\mathrm{y}} \cdot \mathrm{zH}_{2} \mathrm{O}\end{array}$ & $\begin{array}{l}\text { Typically as a primary mineral in granite pegmatites; rare in } \\
\text { carbonatites }\end{array}$ & $<30$ \\
\hline Betauranophane & $\mathrm{Ca}\left(\mathrm{UO}_{2}\right)_{2}\left(\mathrm{SiO}_{3} \mathrm{OH}\right)_{2} \cdot 5 \mathrm{H}_{2} \mathrm{O}$ & $\begin{array}{l}\text { Secondary mineral in uranium deposits, in oxidised ores, } \\
\text { granite veins and pegmatites }\end{array}$ & 60 \\
\hline Boltwoodite & $(\mathrm{K}, \mathrm{Na})\left(\mathrm{UO}_{2}\right)\left(\mathrm{SiO}_{3} \mathrm{OH}\right) \cdot 1.5 \mathrm{H}_{2} \mathrm{O}$ & $\begin{array}{l}\text { Occurs as secondary alteration crusts around uraninite, in } \\
\text { fracture-filling veins, in pegmatites and sandstone-hosted } \\
\text { uranium deposits. }\end{array}$ & 55 \\
\hline Brannerite & $\left(\mathrm{U}^{4+}, \mathrm{REE}, \mathrm{Th}, \mathrm{Ca}\right)\left(\mathrm{Ti}, \mathrm{Fe}^{3+}, \mathrm{Nb}\right)_{2}(\mathrm{O}, \mathrm{OH})_{6}$ & $\begin{array}{l}\text { In granites and pegmatites and as a detrital material in a } \\
\text { gold-bearing placer. }\end{array}$ & 35 \\
\hline Carnotite & $\mathrm{K}_{2}\left(\mathrm{UO}_{2}\right)_{2}\left(\mathrm{VO}_{4}\right)_{2} \cdot 3 \mathrm{H}_{2} \mathrm{O}$ & $\begin{array}{l}\text { A secondary mineral resulting from the alteration of } \\
\text { uraninite, montroseite, or davidite. Occurs in sandstones, } \\
\text { especially in palaeochannels, near fossil carbonaceous matter, } \\
\text { in calcretes and near playas. }\end{array}$ & 55 \\
\hline Coffinite & $\left(\mathrm{U}^{4+}, \mathrm{Th}\right)\left(\mathrm{SiO}_{4}\right)_{1-\mathrm{x}}(\mathrm{OH})_{4 \mathrm{x}}$ & $\begin{array}{l}\text { In unoxidised uranium-vanadium (U-V) deposits, replacing } \\
\text { organic material in sandstone }\end{array}$ & 75 \\
\hline Davidite & $\begin{array}{l}{\left[\left(\mathrm{Fe}^{2+}, \mathrm{REE}, \mathrm{U}, \mathrm{Ca}, \mathrm{Zr}, \mathrm{Th}\right)_{6}\right.} \\
\left.\left(\mathrm{Ti}, \mathrm{Fe}^{3+}, \mathrm{V}, \mathrm{Cr}\right)_{15}(\mathrm{O}, \mathrm{OH})_{36}\right]\end{array}$ & Pegmatites and leucogranites & 5 \\
\hline Francevillite & $\mathrm{BaPb}\left(\mathrm{UO}_{2}\right)_{2}\left(\mathrm{VO}_{4}\right)_{2} \cdot 5 \mathrm{H}_{2} \mathrm{O}$ & $\begin{array}{l}\text { In the oxidised zone of lead-bearing uranium-vanadium } \\
\text { deposits }\end{array}$ & 50 \\
\hline Gummite & $\begin{array}{l}\text { A mixture of uraninite and secondary } \\
\text { uranium minerals of variable composition }\end{array}$ & Forms by oxidation and hydration of uranium minerals & variable \\
\hline Kasolite & $\mathrm{Pb}\left(\mathrm{UO}_{2}\right)(\mathrm{SiO})_{4} \cdot\left(\mathrm{H}_{2} \mathrm{O}\right)$ & $\begin{array}{l}\text { A secondary oxidation product of uraninite alteration in } \\
\text { sedimentary rocks }\end{array}$ & 40 \\
\hline Metahaiweeite & $\mathrm{Ca}\left(\mathrm{UO}_{2}\right) 2 \mathrm{Si}_{6} \mathrm{O}_{15} \cdot \mathrm{nH}_{2} \mathrm{O}$ & $\begin{array}{l}\text { On joints and fractures in granites and granite pegmatites } \\
\text { and in voids in poorly consolidated lake bed sediments }\end{array}$ & 50 \\
\hline Montroseite & $\left(\mathrm{V}^{3+}, \mathrm{Fe}^{3+}\right) \mathrm{O}(\mathrm{OH})$ & In relatively unoxidised U-V ores in sandstones & traces \\
\hline Pitchblende & $\mathrm{UO}_{2}+\mathrm{U}_{3} \mathrm{O}_{8}$ & Massive black uraninite & $60-70$ \\
\hline Sklodowskite & $\mathrm{Mg}\left(\mathrm{UO}_{2}\right)_{2}\left(\mathrm{SiO}_{3} \mathrm{OH}\right)_{2} \cdot 6 \mathrm{H}_{2} \mathrm{O}$ & A secondary mineral formed from uraninite & 55 \\
\hline Thorogummite & $(\mathrm{Th}, \mathrm{U})\left(\mathrm{SiO}_{4}\right)_{1-\mathrm{x}}(\mathrm{OH})_{4 \mathrm{x}}$ & $\begin{array}{l}\text { This name has been used to describe heterogeneous mixtures } \\
\text { of secondary, non-crystalline minerals, produced by the } \\
\text { alteration, hydration, or metamictisation of thorite. } \\
\text { Use discredited in } 2014\end{array}$ & $<10$ \\
\hline $\begin{array}{l}\text { Torbernite and } \\
\text { meta-torbernite }\end{array}$ & $\mathrm{Cu}\left(\mathrm{UO}_{2}\right)_{2}\left(\mathrm{PO}_{4}\right)_{2} \cdot 12 \mathrm{H}_{2} \mathrm{O}$ & $\begin{array}{l}\text { A secondary mineral found in the oxidised zones of some } \\
\text { uraniferous copper deposits. Often dehydrated to } \\
\text { metatorbernite }\end{array}$ & 50 \\
\hline Tyuyamunite & $\mathrm{Ca}\left(\mathrm{UO}_{2}\right)_{2}\left(\mathrm{VO}_{4}\right)_{2} \cdot 5-8 \mathrm{H}_{2} \mathrm{O}$ & $\begin{array}{l}\text { A secondary mineral in calcrete-hosted deposits and in veins, } \\
\text { disseminated in the limestone or as fillings in karst caverns }\end{array}$ & 52 \\
\hline Uraninite & $\mathrm{UO}_{2}$ & $\begin{array}{l}\text { Occurs in granitic and syenitic pegmatites. Colloform crusts } \\
\text { in high temperature hydrothermal veins. In quartz-pebble } \\
\text { conglomerates. }\end{array}$ & 88 \\
\hline Uranophane & $\mathrm{Ca}\left(\mathrm{UO}_{2}\right)_{2}\left(\mathrm{SiO}_{3} \mathrm{OH}\right)_{2} \cdot 5 \mathrm{H}_{2} \mathrm{O}$ & Secondary mineral in uranium deposits and pegmatites & 40 \\
\hline Uranothallite & $\mathrm{Ca}_{2}\left(\mathrm{UO}_{2}\right)\left(\mathrm{CO}_{3}\right)_{3} \cdot 10 \mathrm{H}_{2} \mathrm{O}$ & $\begin{array}{l}\text { Secondary mineral formed by alteration of uraninite in } \\
\text { alkaline carbonate solutions }\end{array}$ & \\
\hline Uranothorite & $(\mathrm{Th}, \mathrm{U}) \mathrm{SiO}_{4}$ & $\begin{array}{l}\text { Widespread in pegmatites, volcanic rocks, hydrothermal } \\
\text { veins and contact metamorphic rocks }\end{array}$ & 32 \\
\hline
\end{tabular}


Heinrich, a calcrete-hosted deposit discovered in 1973 by Gencor, $80 \mathrm{~km}$ inland from Walvis Bay and $50 \mathrm{~km}$ southeast of Rössing. More recently, several primary-hosted deposits have been developed including the world-class Husab deposit.

In Niger, uranium was discovered at Azelik in 1957 by the French Bureau de Recherches Géologiques et Minières (BRGM) who were looking for copper. Further discoveries were made in the late 1950s and 1960s including Abokurum (1959), Madaouela (1963), Arlette, Ariege, Artois \& Tassa/Taza (1965), Imouraren (1966) and Akouta (1967), and on the basis of these discoveries Niger's uranium industry was founded in 1968, with the first production from Arlit in 1971. Capacity was expanded to $2,100 \mathrm{tU} / \mathrm{yr}$ in 1981 and at its peak in the 1980 s, $40 \%$ of the world's uranium production came from Arlit, and uranium represented 90\% of Niger's exports by value. In 1981 production was cut by half and in the late 1980s, Arlit suffered from a steep decline in world uranium prices. The value of Niger's uranium "boom" has never recovered to its 1980s level.

In South Africa, radioactivity was noted in the gold-bearing conglomerates of the Witwatersrand in 1915 (Whiteside, 1970). Uranium production began in 1951, peaking in 1959 when 26 mines, feeding 17 plants, supplied 4,954 tU (Cole, 1998). This material was exported for the nuclear weapons programme but with its curtailment, output was reduced until the world oil crisis in 1973, when uranium production resumed as a source for nuclear energy so that by 1980 , 20 mines produced 6,000 $\mathrm{tU}$ (Cole, 1998). The price slump in 1980 led to reduced output so that by 1994 only 3 producers remained. Most uranium has been a by-product of gold mining from the Witwatersrand Basin (McCarthy, 2006), although there has also been production as a by-product of copper mining from the carbonatite at Palabora and uranium resources have previously been evaluated in the Permo Triassic-aged Karoo Basin. From 1950 uranium was used in nuclear reactors. In spite of this there are only two active nuclear reactors generating electricity in Africa, at Koeberg in the Western Cape province of South Africa, with one nuclear reactor at Pelindaba in South Africa producing nuclear isotopes for medical purposes.

\section{Occurrences of uranium}

The primary deposits shown in Fig. 1 are those where mines extract uranium as the main, or sole commodity, whereas those shown

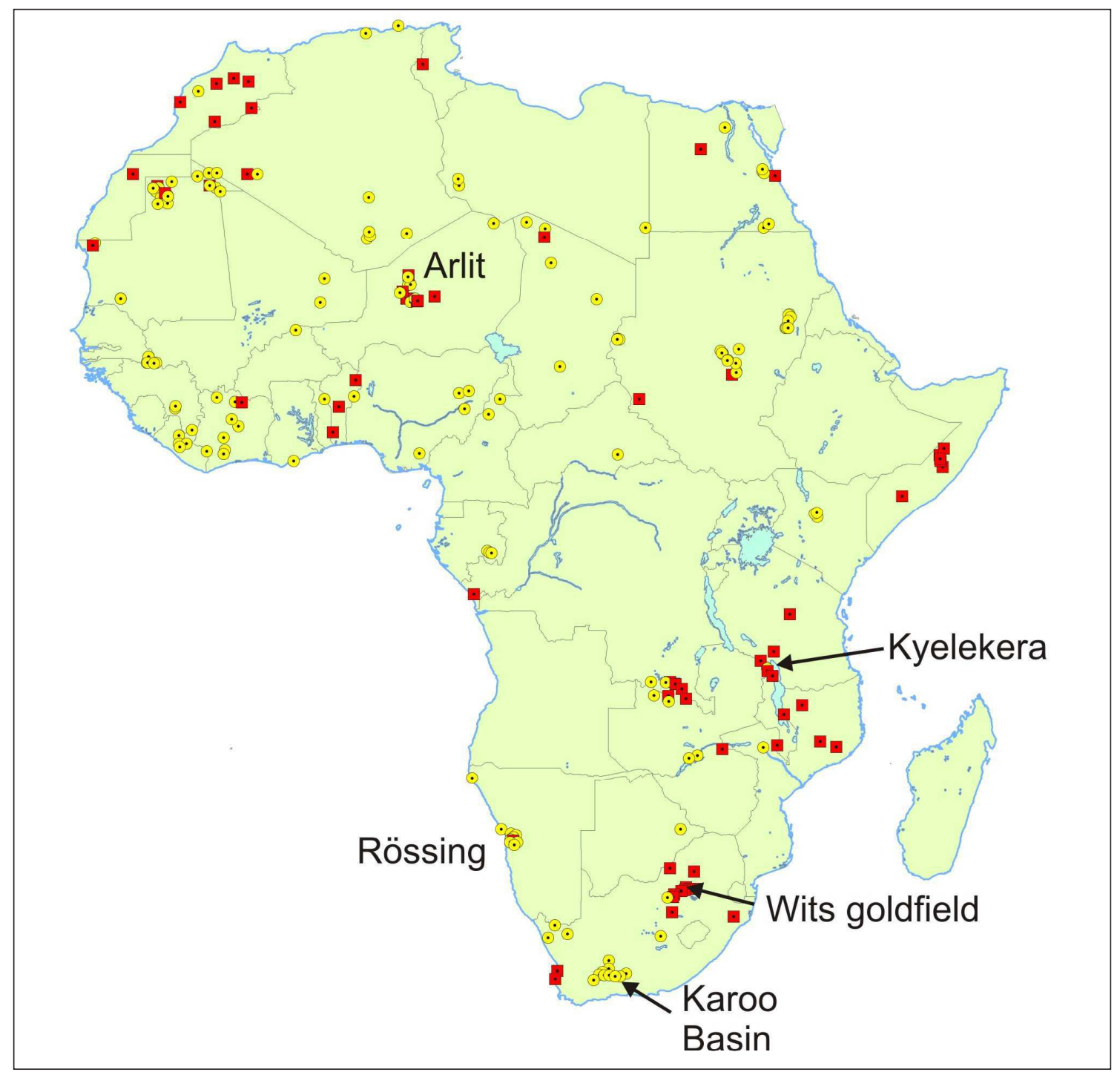

Fig. 1. Primary deposits shown in yellow circles are those where uranium occurs as the main, or sole commodity, whereas those shown as secondary deposits in red squares, such as the Witwatersrand Basin, produce another commodity as the prime metal with uranium as a byproduct. 
as secondary deposits such as the Witwatersrand Basin, produce another commodity as the prime metal with uranium as a byproduct.

There are a number of different geological settings for major uranium deposits around the world. Some types, such as the intrusive type, sandstone-hosted and surficial deposits, are well represented in Africa. Some styles, such as unconformity-related deposits are not well represented, although the potential for such deposits occurring at the contact between basement and uranium-bearing cover rocks must remain considerable. Uranium deposits in Africa range in age from Archaean, in the Witwatersrand goldfield, to Pleistocene calcretehosted deposits in Namibia. The Pan-African amalgamation of Gondwana, in the late Proterozoic, resulted in the intrusion of granites and pegmatites at the end of the orogeny in the period 550-490 Ma and uranium enrichment associated with these granites and pegmatites occurs in Namibia, Nigeria, Somaliland, and Mozambique.

There are four major types of deposits that produce the majority of the uranium in Africa. These are the Archaean quartz-conglomerate hosted gold-uranium deposits of South Africa; the Neoproterozoic end-orogeny sheeted leucogranites and small stocks of Namibia; the Mesozoic sandstone-hosted roll-front deposits of Niger and Malawi; and the recent channel-hosted calcrete and alluvial deposits in Namibia, which locally have huge economic viability. Minor unconformity-style deposits occur in Algeria and Malawi, phosphatehosted deposits in Morocco and offshore South Africa, vein-hosted deposits at Shinkolobwe in the DRC and Lumwana in Zambia. In Namibia, uranium occurs in chert veins cross-cutting Damaran metasediments at Rössing Mine, in fluorite veins at Husab (Jacob, 1974b) and calcite-boltwoodite veins near Goanikontes (Palfi et al., 2001).

Namibia constitutes a uraniferous province with known uranium enrichment occurring over a period of 2000 Ma ranging from Eburnean basement granite gneiss, through Neoproterozoic Damaran metasedimentary rocks and intrusives, in Mesozoic granite complexes related to Gondwana fragmentation and carnotite-rich calcrete and siliciclastic hosted surficial deposits which developed from late Tertiary times. Similarly, in South Africa, uranium deposits occur in Archaean quartz pebble conglomerates, in a Palaeoproterozoic carbonatite, in Permo-Triassic Karoo sandstones, with concentrations also in granites of the Cape Suite near George that are late Proterozoic to Cambrian in age, in granite gneiss and pegmatites of the Namaqualand Metamorphic complex and in Recent lacustrine deposits, as at Henkries and pedogenic concentrations and marine phosphates (Cole, 1998).

\section{Granite-hosted uranium deposits}

Many anorogenic granites, such as those of Nigeria and Namibia, are enriched in uranium, although concentrations are generally not sufficiently elevated to warrant exploitation. In Nigeria, Mesozoic peralkaline and metaluminous granites occur in more than 50 complexes extending from the Niger border to the Benue Valley. In Namibia, granite magmatism at the end of the Damaran orogeny was important for uranium mineralisation, whilst granite ring complexes (190-120 Ma) that are aligned along northeast-southwest trending lineaments that link with offshore transform faults, were important sources of uranium for calcretehosted deposits.

\section{Namibia}

Uranium-enriched leucogranite sheets intruded late in the Damaran orogeny (around $\sim 500 \mathrm{Ma}$ ) in west central Namibia (Fig. 2), into Neoproterozoic metasedimentary rocks of 780-746 Ma (Gray et al., 2008), often close to outcrops of basement gneisses $2 \mathrm{Ga}$ in age, and domes (Kroner et al., 1991; Longridge, 2012). These sheeted leucogranites occur in a corridor $\sim 70 \mathrm{~km}$ long and $30 \mathrm{~km}$ wide, in a belt of high-temperature, low pressure metamorphism of the south Central Zone of the Neoproterozoic Damara Orogen (Kinnaird and Nex, 2007). The sheets can be divided into six different types based on field characteristics of colour, grain-size, structural setting and mineralogy (Nex and Kinnaird, 1995; Nex, 1997; Nex et al., 2001b; Freemantle, 2012). Of these six types of leucogranite (A$\mathrm{F})$, three pre- $\mathrm{D}_{3}$ types are barren while post $\mathrm{D}_{3}$ alaskites are undeformed and more prospective for uranium, especially types D and $\mathrm{E}$ (Table 2). Early workers termed these leucogranites alaskites (Jacob, 1974b), a term introduced by Spurr in 1900 to describe palecoloured alkali feldspar-rich granites with a low percentage of mafic minerals. However, the sheeted uranium-bearing leucogranites range in composition from granodiorite, through monzo- and syenogranite to alkali feldspar granite (Kinnaird and Nex, 2007). There is a stratigraphic control on the location of the mineralised sheets close to the Khan-Rössing Formation boundary, or to the Khan-Chuos Formation boundary. This stratigraphic boundary marks a transition from dominantly terrigenous sedimentation in the Khan Formation, to the calcsilicates and marbles intercalated with quartzites and mica schists of the Rössing Formation. Increased availability of carbon dioxide $\left(\mathrm{CO}_{2}\right)$ may have affected the oxidation-reduction potential of the uranium within the crystallising leucogranites (Kinnaird et al., 2009a, 2009b). Where the Rössing Formation is thin or absent, such as at Valencia, granite sheets intrude higher up into the Karibib Formation (Fig. 3). Structural controls on emplacement appear to be related to the transition from ductile to brittle deformation, with local controls varying from emplacement in en-echelon tension gashes related to sinistral transpression on the margins of a dome at Rössing (Basson and Greenway, 2004), emplacement along a high strain zone at Goanikontes (Kinnaird and Nex, 2007), in a saddle-reef at Valencia (Freemantle, 2012) and marginal to the Kuiseb syncline at Husab (Spivey, 2010) (Fig. 3).

The leucogranite sheets are white, to grey or pink in colour and texturally range from granophyric or aplitic, to coarse-grained and pegmatitic (Kinnaird and Nex, 2007). The sheets vary from a few centimetres in width, especially for the early veins, to >100 m across and the larger sheets, some of which may be composite, occur as cross-cutting irregular, anastomosing dykes and as concordant bodies intruded along the gneissosity in the Damaran sediments. The leucogranites are comprised essentially of quartz and feldspar, which may be a combination of microcline, perthite, albite or oligoclase, with $<5 \%$ mafic minerals. Accessory minerals are sparse in abundance but vary in composition according to the type of host rock, whether an early or late intrusion and the proximity to the margin of the stock or sheet (Kinnaird and Nex, 2007). Smoky quartz is diagnostic of a high uranium content.

Uraninite is the dominant primary uranium-bearing mineral with minor betafite, brannerite and davidite which may be locally abundant. The uraninite forms black, resinous subhedral to euhedral crystals, 3-5 $\mathrm{mm}$ in size in microcline or plagioclase, or at crystal boundaries between feldspar, quartz and biotite. It is surrounded by alteration 
Table 2. Field characteristics of the six different types of sheeted leucogranites based on the scheme of Nex \& Kinnaird 1995; Nex (1997), Freemantle (2012).

\begin{tabular}{|c|c|c|}
\hline Type & Description & $\begin{array}{l}\text { Scintillometer } \\
\text { Measurements }\end{array}$ \\
\hline A-type & $\begin{array}{l}\text { Infrequent: thin }<1 \mathrm{~m} \text { wide, irregular in form, very light pink, cream to white, bedding-parallel, very few } \\
\text { accessories, often foliated, folded and boudinaged with prominent biotite streaks at margins. }\end{array}$ & low \\
\hline B-type & $\begin{array}{l}\text { Common: up to } 10 \mathrm{~m} \text { thick, light pink, garnetiferous, either medium- to fine-grained and homogeneous } \\
\text { or pegmatitic with clear quartz. Often bedding parallel, folded and boudinaged. Garnet occurs in clusters } \\
\text { or as disseminated grains mostly }<1 \mathrm{~cm} \text { in size, with sillimanite in the pegmatitic facies within the } \\
\text { Kuiseb Formation at Valencia. }\end{array}$ & low \\
\hline $\begin{array}{l}\text { C-type } \\
\text { (accessory-free) }\end{array}$ & $\begin{array}{l}\text { Widespread, extensive sheets or coalescences of sheets, predominantly in upper Nosib and Swakop Groups, } \\
\text { white to light pink in colour, variably coarse-grained occasionally boudinaged, minimal accessories except } \\
\text { entrained biotite. }\end{array}$ & low \\
\hline $\begin{array}{l}\text { C-type } \\
\text { (tourmaline) }\end{array}$ & $\begin{array}{l}\text { Widespread, typically } 2-5 \mathrm{~m} \text { across. Light pink or white, mostly fairly coarse-grained to pegmatitic, } \\
\text { occasionally boudinaged with massive tourmaline }<6 \mathrm{~cm} \text {, often in clusters. Occur parallel to bedding in } \\
\text { Kuiseb and Khan schists and gneisses. }\end{array}$ & low \\
\hline $\begin{array}{l}\text { C-type } \\
\text { (magnetite) }\end{array}$ & $\begin{array}{l}\text { Uncommon, > } 1 \mathrm{~m} \text { across, occur parallel to bedding/cleavage/foliation. Distinctive pink and white colour, } \\
\text { medium to very coarse as well as pegmatitic in patches. Magnetite is the dominant accessory as clusters or } \\
\text { disseminated throughout. These may also have accessory tourmaline accompanied by clear quartz. }\end{array}$ & $\begin{array}{l}\text { low-high } \\
\text { in patches }\end{array}$ \\
\hline D-type & $\begin{array}{l}\text { Common but localised sheeted intrusion, often at the Khan-Rössing boundary but extend into Chuos or } \\
\text { higher where the Rössing Formation is attenuated or absent. White and black or grey patches, medium to } \\
\text { coarse-grained generally homogeneous granular texture, sometimes banded, smoky quartz and very little } \\
\text { accessory biotite. May have yellow uranium secondary phases on exposed surfaces and on joint planes. }\end{array}$ & very high \\
\hline E-type & $\begin{array}{l}\text { Common but localised, generally tabular, occasionally bifurcating, highly haematised light pink to deep } \\
\text { red inhomogeneous. Smoky quartz, biotite content variable. They are interpreted to be hydrothermally } \\
\text { altered D-types (1997). }\end{array}$ & $\begin{array}{l}\text { high-very } \\
\text { high }\end{array}$ \\
\hline F-type & $\begin{array}{l}\text { Widespread but not abundant. Tabular, parallel-sided, deep brick red to pink, coarse to pegmatitic, } \\
\text { characteristic milky quartz, cross cuts most features and granites. }\end{array}$ & low \\
\hline
\end{tabular}

zones and radial cracks. Many uraninite crystals are altered in their core to thorite $\left((\mathrm{Th}, \mathrm{U}) \mathrm{SiO}_{4}\right)$, jarosite $\left(\mathrm{KFe}_{3}^{3+}\left(\mathrm{SO}_{4}\right)_{2}(\mathrm{OH})_{6}\right)$ and secondary uranium minerals and uranium-rich rims are also lead $(\mathrm{Pb})$ rich (Kinnaird and Nex, 2007). Betafite is commonly dark or yellowish brown, occasionally grey to reddish brown or almost black. It has a resinous lustre and conchoidal fracture and occurs as small octahedral to sub-rounded isolated dodecahedral crystals or clusters of crystals up to $2 \mathrm{~cm}$ in size, although commonly of 1-3 mm diameter, characteristically surrounded by a 5-10 $\mathrm{mm}$ orange-coloured altered rim composed of limonite, 1-2 mm sized galena, $\mathrm{TiO}_{2}$-bearing minerals and clays. Betafite is surrounded by a halo of radial cracks permeated with red or yellow secondary uranium-, iron- and titanium-bearing minerals (Kinnaird and Nex, 2007). Brannerite occurs as brownish pleochroic euhedral crystals up to $2 \mathrm{~mm}$ in size with alteration along internal and surrounding radial fractures. It is not a common mineral but it occurs locally in mafic enclaves within granite sheets. The mafic clusters comprise chloritised biotite, rutile, sphene, and magnetite with chlorite veinlets, epidote, fluorite and pyrite.

Secondary betauranophane/uranophane or coffinite with metatorbernite, metahaiweeite, carnotite, gummite and thorogummite, may account for $10-55 \%$ of the uranium budget (von Backström, 1970). Other minerals have been reported including, autunite, uraniferous monazite, boltwoodite, torbernite and uranothallite (Kinnaird and Nex, 2007 and references therein). Compositions of these minerals are shown in Table 1.

The major producer of uranium by open pit production from granite sheets is the Rössing Mine (Table 3). Other primary granitehosted anomalies in the south Central Zone of the Damara Orogen currently under exploration and evaluation or development are Husab
(Rössing South), Valencia, the Ida Dome, and Etango (Goanikontes) deposits (Fig. 2) (Mouillac, et al., 1986; Nex \& Kinnaird, 1995; Nex, 1997; Nex et al., 2001b). Reserves for these various deposits are shown in Table 3, with 6 year output given in Table 4 and detailed characteristics of major deposits are shown in Fig. 3.

\section{Rössing}

Semi-pelitic gneisses of the Khan Formation together with younger marbles, semi-pelites and conglomerates of the Rössing Formation, are separated from the current-bedded fluviatile Etusis Formation quartzites and schists of the Rössing Dome by a high strain zone (Oliver and Kinnaird, 1996). Uranium-bearing crustally-derived, post-collisional sheeted leucogranites of Cambrian age intruded Damaran metasediments and pre-Damaran basement to the southwest of the dome (Herd, 1996; Nex, 1997; Nex et al., 2002, Basson \& Greenway, 2004; Kinnaird \& Nex, 2007). There are four uranium anomalies in the area: the SJ, SH, SK and Z20. Only the SJ area (the main pit), which is to the southwest of the Rössing Dome is currently exploited. Major dome and basin and hook geometries resulted from $\mathrm{F}_{2}-\mathrm{F}_{3}$ fold interference (Longridge, 2012; Gray, 2015). $\mathrm{D}_{3}$ to $\mathrm{D}_{4}$ deformation was progressive with the development of early, minor north-northeasterly trending folds and left lateral faulting, followed by the formation of north-northeasterly oriented transtensional shear zones highly oblique to pre- $\mathrm{D}_{4}$ litho-structural orientations and into which uranium-bearing granitic melts were focussed (Gray, 2015). Sheeted leucogranites in the $\mathrm{SH}$ area preferentially intrude along the axial plane of $\mathrm{a}_{3}$ fold core. The Rössing open pit, which is around $3 \mathrm{~km}$ long in a southwest-northeasterly direction, $500 \mathrm{~m}$ wide and $350 \mathrm{~m}$ deep (Fig. 4a), mines leucogranites and country rock. 


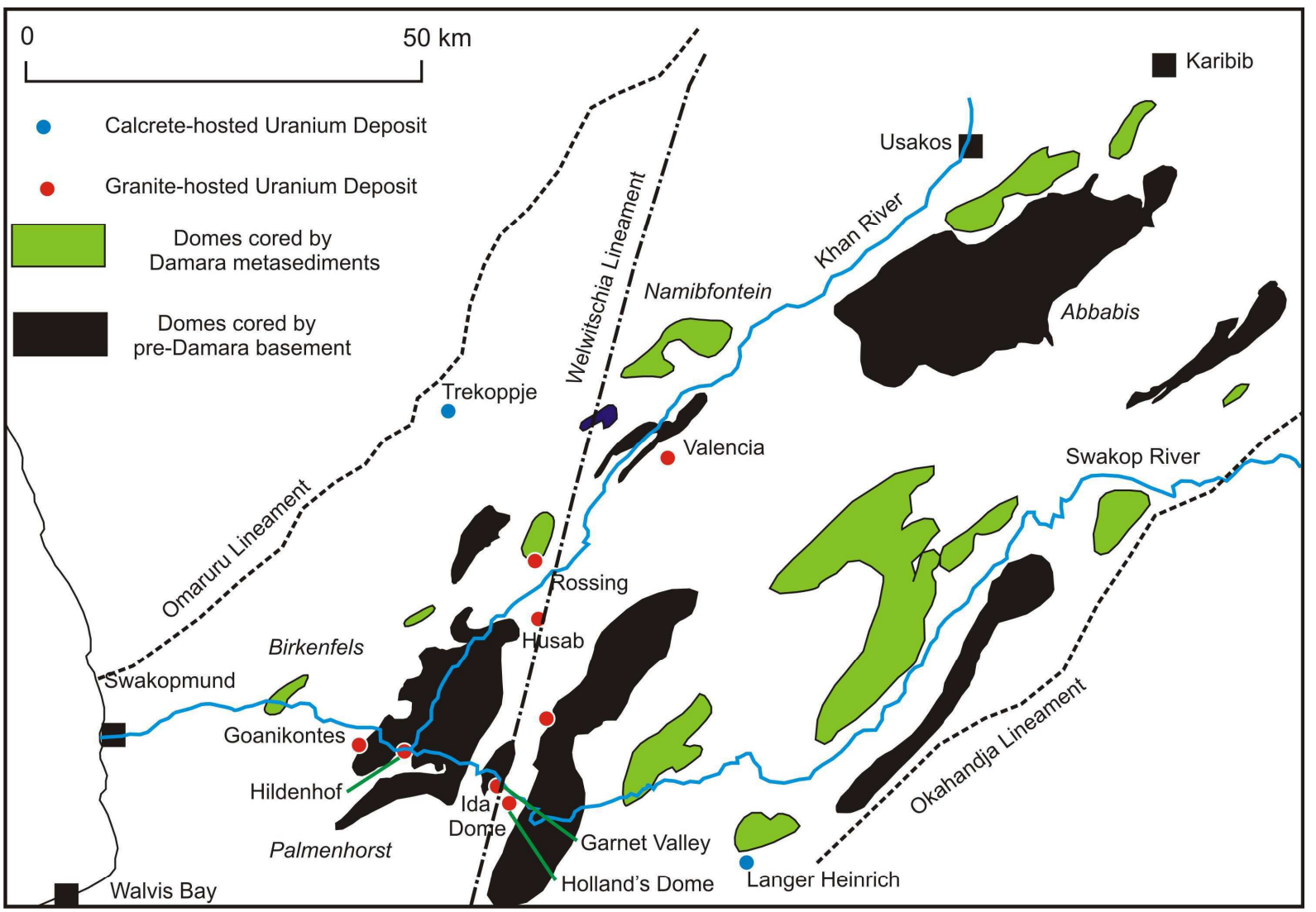

Fig. 2. Location map of uranium deposits in the south Central Zone of the Damara Orogen in Namibia and the distribution of domes.

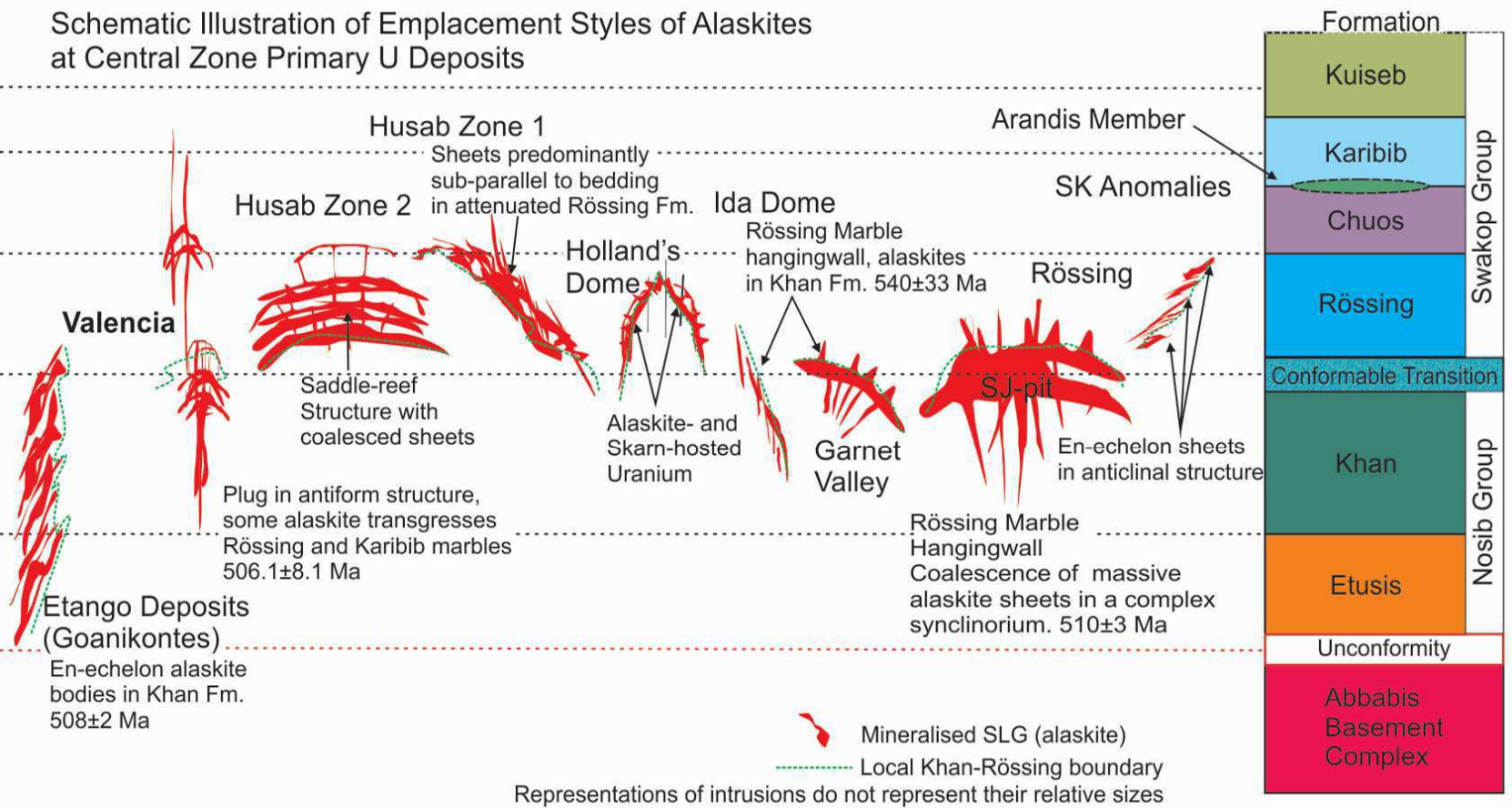

Fig. 3. Mineralised leucogranites intrude a number of lithologies of the Central Zone. Most of the mineralisation is focused at the KhanRössing boundary, which is represented as a transitional contact marked by the first appearance of marble. The top of the Khan is characterised by diopsidic gneisses and amphibole-biotite schist. Where attenuation has occurred, as at Valencia, mineralised sheets have intruded into the upper Swakop Group (Chuos, Karibib, Kuiseb) lithologies. Ages of mineralised intrusives are from: Longridge et al. (2012) (Valencia); Briqueu et al. (1980) (Goanikontes); Marlow, (1983) (Ida Dome) and an inferred date from monazite in the Khan Formation at Rössing (Basson and Greenway, 2004). Abbabis age from Miller (2008). Diagram from Freemantle (2015). 


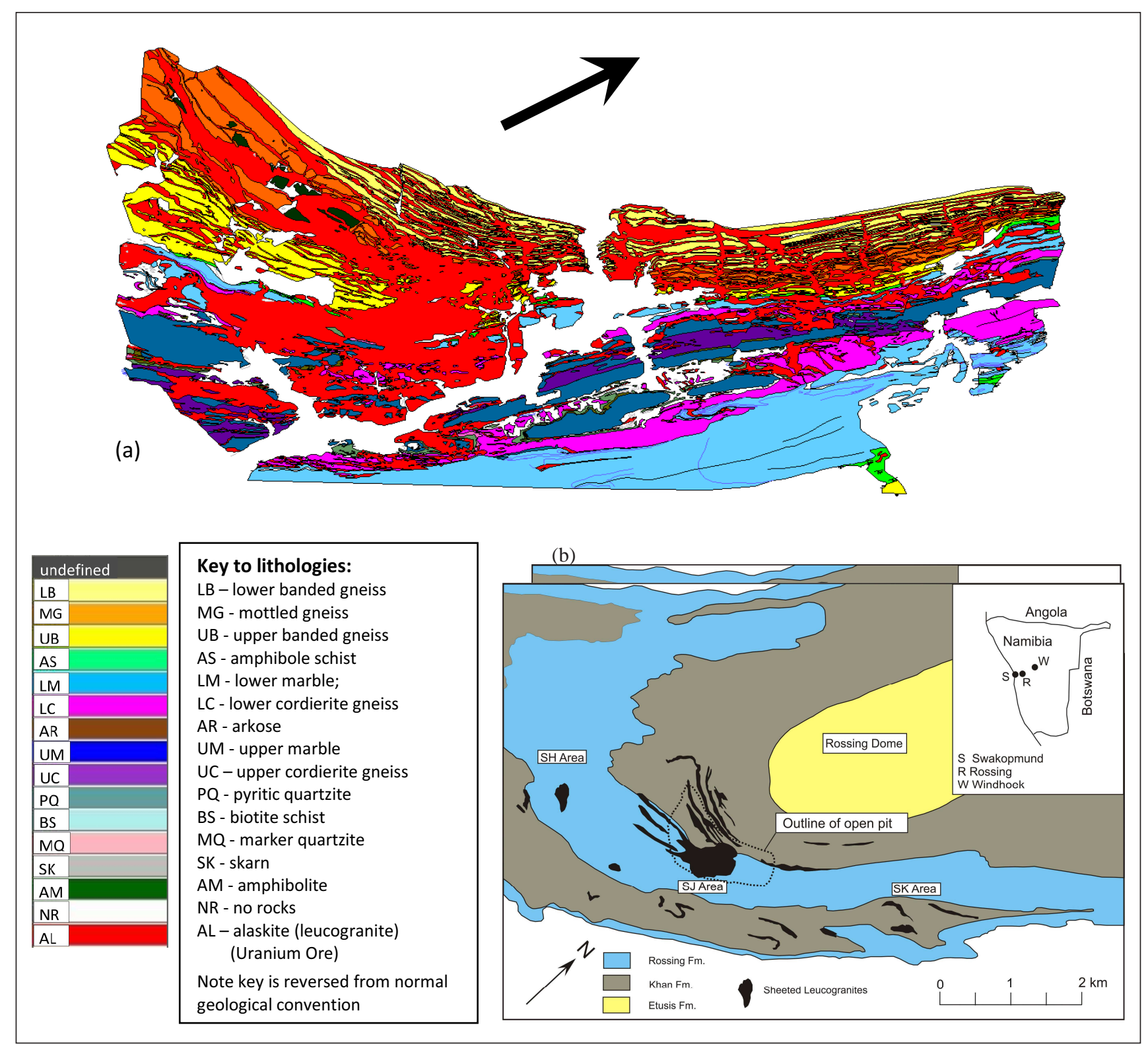

Fig. 4. The Rössing area geology (a) Geological map of the main pit in the SJ area. The pit is 3 km in length (b) Location of the SJ, SK and SH areas with inset showing the location of Rössing.

Rössing Mine has a production capacity of 4,000 tU per year, although as Table 4 shows, output in recent years has been much less. There is an anticipated life-of-mine until 2023 although mine-site exploration may extend this and heap-leach techniques are being tested that may increase production. In 2013 resources for the Z20 orebody, south of the main pit, were quoted, with 46,274 tU at higher grades than the main orebody, and in 2014 development was said to be feasible when the uranium price returned to US\$ $60 \mathrm{lb}$. Rössing reserves are shown in Table 3. To the end of 2011 Rössing had supplied 101,123 tU (Table 4).

\section{Husab}

The Husab project, formerly Rössing South, occurs $56 \mathrm{~km}$ inland from Swakopmund and $7 \mathrm{~km}$ across the Khan Gorge from the Rössing deposit (Fig. 2). It was targeted for exploration in 2006 because aeromagnetic data suggested that the Damaran stratigraphy and structure beneath the gravel plain shared many structural and stratigraphic characteristics with the Rössing deposit. In addition, the Khan-Rössing Formation contact on both limbs of the Kuiseb syncline (Fig. 5) could be seen in the Khan River gorge where weakly mineralised leucogranite sheets occurred. Aeromagnetic data further suggested that, on the eastern limb of the Kuiseb syncline, there was an extensive occurrence of faulted Khan Formation lithologies (Spivey et al., 2010). This, combined with the fact that known uranium mineralisation occurs in the Z19 area of the Rössing mining license some $2.5 \mathrm{~km}$ to the north, led to target drilling in 2007 on the Husab license, which resulted in mine development in 2013.

Uranium mineralisation occurs beneath $10-80 \mathrm{~m}$ of sands and gravels of the Namib Plain. Numerous mineralised leucogranite sheets are preferentially concentrated in the Rössing Formation on the eastern faulted flank of the major north-northeasterly trending Kuiseb syncline and east limb of the Rössing South anticline cored by amphibole pyroxene gneiss of the Khan Formation (Fig. 5 and 6b). In contrast 
Table 3. Reserves of the granite-hosted uraniferous deposits in Namibia (World Nuclear Authority March 2015)

\begin{tabular}{|l|l|c|}
\hline & Measured and indicated & Inferred \\
\hline $\begin{array}{l}\text { Husab } \\
\text { (Rössing S) }\end{array}$ & $137,700 \mathrm{tU}$ in $0.039 \%$ ore & $50,000 \mathrm{tU}$ in $0.029 \%$ ore \\
\hline Rössing Z20 & $20,656 \mathrm{tU}$ in $0.024 \%$ ore & $25,354 \mathrm{tU}$ in $0.022 \%$ ore \\
\hline Etango & $57,330 \mathrm{tU}$ in $0.019 \%$ ore & $24,630 \mathrm{tU}$ in $0.016 \%$ ore \\
\hline $\begin{array}{l}\text { Norasa (Valencia } \\
\text { and Namibplaats) }\end{array}$ & $39,700 \mathrm{tU}$ in $0.0167 \%$ ore & $8,500 \mathrm{tU}$ in $0.014 \%$ ore \\
\hline Omahola & $10,400 \mathrm{tU}$ in $0.036 \%$ ore & $6,950 \mathrm{tU}$ in $0.036 \%$ ore \\
\hline Rössing SJ & $25,866 \mathrm{tU}$ in $0.02 \%$ ore & $2,035 \mathrm{tU}$ in $0.017 \%$ ore \\
\hline
\end{tabular}

Table 4. Production from granite-hosted uranium deposits in metric tonnes (World Nuclear Authority March 2015).

\begin{tabular}{|l|l|l|l|l|l|l|l|}
\hline & 2008 & 2009 & 2010 & 2011 & 2012 & 2013 & 2014 \\
\hline $\begin{array}{l}\text { Langer } \\
\text { Heinrich }\end{array}$ & 919 & 1,108 & 1,419 & 1,437 & 1,960 & 2,098 & 2,297 \\
\hline Rössing & 3,449 & 3,519 & 3,083 & 2,641 & 2,289 & 2,043 & 1,308 \\
\hline Trekkopje & 0 & 0 & 0 & 0 & 251 & 186 & $0 ?$ \\
\hline Total & & & & 4,078 & 4,500 & 4,327 & 3,605 \\
\hline
\end{tabular}

to Rössing to the north and the Ida Dome, to the south at Husab, thick Rössing Formation marbles are lacking (Spivey, 2010). The mineralised zone extends at least $10 \mathrm{~km}$ along strike. The first mineralisation was identified on the eastern limb of the Rössing South anticline, but since then significant mineralisation has been identified on the western limb in both zones 1 and 2 (Fig. 6a). The mineralisation on the western limb in zone 1 is steeply dipping but becomes shallower dipping in Zone 2 (Spivey et al., 2010). Lithologic dips are steeper in Zone 1 than Zone 2 and the sheeted bodies are generally semiconformable to lithological boundaries.

The deposit is dominated by primary uraninite in leucogranite sheets of Types D and E. The uraninite typically occurs as finely disseminated grains that are larger than in other deposits and may reach $<120 \mu \mathrm{m}$ in size (Spivey et al., 2010). This is associated with smoky quartz and abundant coarse-grained biotite and where intervals of $>50 \%$ coarse biotite have been intersected in drill core, high grades of $>2,000 \mathrm{ppm} \mathrm{U}_{3} \mathrm{O}_{8}$ have been recorded (Spivey et al., 2010). Minor brannerite occurs where the leucogranite sheets cross-cut Khan metasedimentary horizons and locally coffinite is significant together with rare thorite, betafite and monazite (Freemantle, pers. comm.). Secondary mineralisation accounts for $20-25 \%$ of the uranium budget. It occurs as fine veinlets and coatings on joint surfaces in calc-silicates, biotite schist and gneiss country rocks (Spivey et al., 2010). The upper $\sim 100 \mathrm{~m}$ of the deposit is often depleted in uranium by as much as $40 \%$, compared to material $>100 \mathrm{~m}$ depth (Spivey et al., 2010).

Taurus Minerals, a subsidiary of China's CGNPC-Uranium Resources Co, started development of the mine in February 2013, and production is expected to commence late in 2015, ramping up to $5,700 \mathrm{tU} / \mathrm{yr}$ by the end of 2017 (WNA, March 2015). The definitive feasibility study by Perth-based Extract Resources showed the technical and economic viability of mining Zones $1 \& 2$ based on a measured resource of $32,000 \mathrm{tU}$ averaging $0.043 \% \mathrm{U}$, and indicated resources of $105,500 \mathrm{tU}$ at $0.037 \%, \mathrm{U}$. Further zones to the south also have substantial resources. The Zone 1 pit will be $1.3 \times 2.5 \mathrm{~km}$ and the Zone 2 pit will be $1.0 \times 1.5 \mathrm{~km}$ (WNA, March 2015). The definitive feasibility study envisages the mining of $15 \mathrm{Mt}$ of ore per year to feed a processing plant producing 5,770 $\mathrm{tU}$ per year. Based on available figures this will be the richest grade primary uranium deposit and fourth largest deposit in the world.

\section{Ida Dome, Garnet Valley, Holland's Dome, New Camp, Ida Central, Ida East}

These deposits are located along the Ida trend which extends $\sim 10$ km from Garnet Valley and Holland's Dome in the south, through to the Ida Central and Ida East deposits (Fig. 2). Mineralisation along this trend is irregularly distributed, uranium-bearing sheeted leucogranites intruding the eastern and southeastern sides of the Ida Dome close to the contact between the Khan Formation and Rössing marbles. Sheets are compositionally and texturally varied, often with enclaves of earlier facies in the later sheets. Bedding-parallel E-type (Table 2) uraniferous sheets in Garnet Valley and the Holland's Dome area, have locally coalesced into small plutons. Locally, extensive calcsilicate and magnetite skarns developed at the contact between the leucogranite and the marbles, with the development of andradite garnet, epidote, sphene, magnetite and scapolite. Uranium mineralisation is also high-grade locally, in magnetite-bearing skarns and on the contacts between sheets and schist xenoliths (Freemantle,

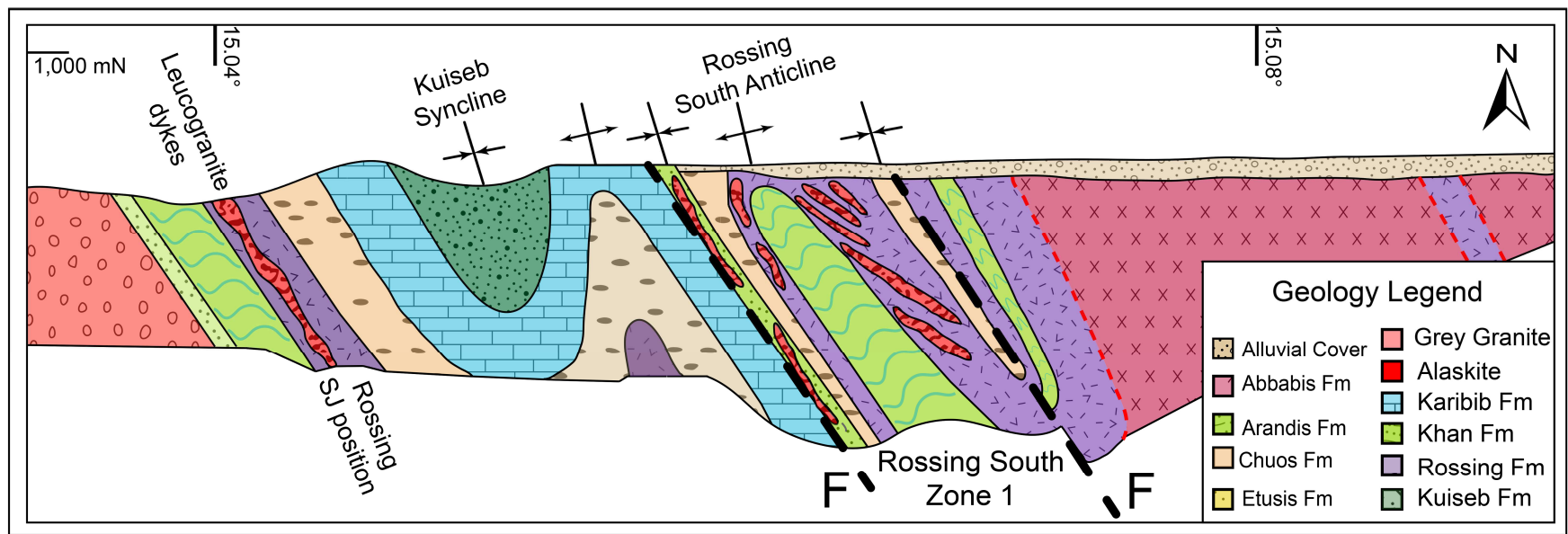

Fig. 5. Generalised geological cross section across Rössing South Zone 1. The Rössing South anticline in Zone 2 becomes more open (Spivey, et al., 2010). The location of Zones 1 and 2 is shown in Fig. $6 a$. 


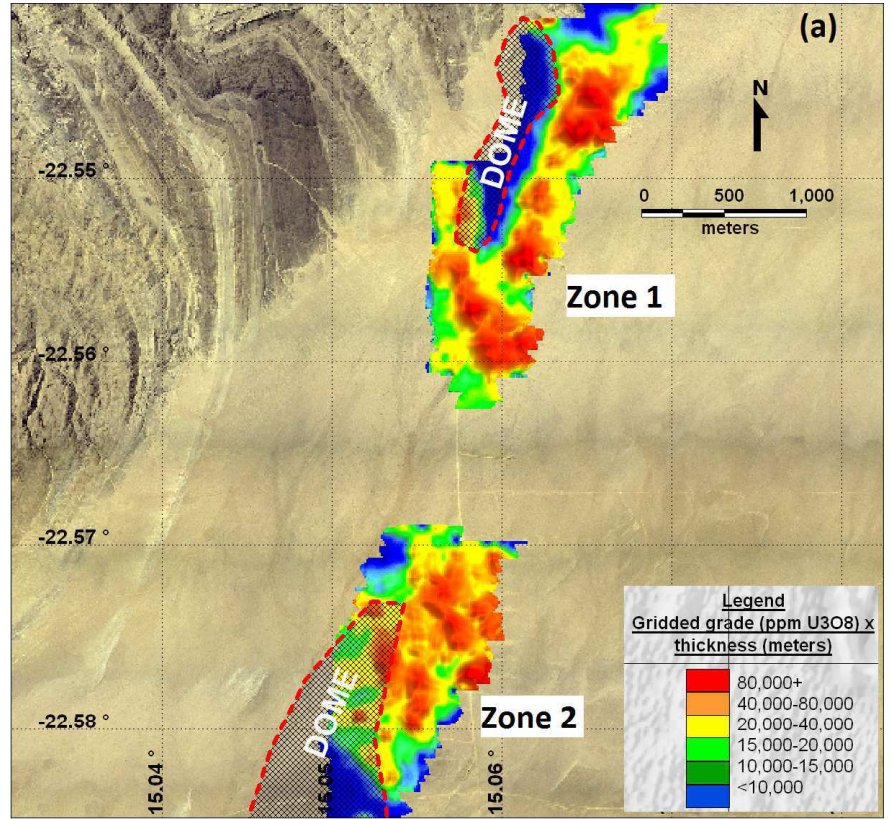

Fig. 6. The Husab deposit (a) Schematic diagram showing the location of Zones 1 and 2 with metal accumulation (grade $x$ thickness) (Spivey et al., 2010) (b) Geological map of the Husab Project showing the extent of mineralisation, from Spivey et al. (2010)

2015). At surface, significant uranium occurs in uranophane with the major primary phase as uraninite and minor brannerite at Ida Central hosting $<4 \%$ of the uranium budget. The proportion of secondary phases decreases with depth. Exploration on the project was suspended by Swakop Uranium as their focus moved to the Husab project, although reserves have been determined.

\section{Etango (Goanikontes)}

The Etango Project of Bannerman Mining Resources is located $\sim 31 \mathrm{~km}$ east of Swakopmund (Fig. 2). South of the Swakop River, post-tectonic granite sheets occur in a high strain zone, on the western margin of a red granite gneiss dome (Fig. 7a). North of the river, abundant Type E sheets intruded at the contact between remnant Rössing marble/calcsilicate and Khan Formation biotite amphibole schist. Uranium-rich Type D sheets (Table 2), which occur in the Rabbit Valley area, now termed the Onkelo prospect (Fig. 7b), are a distinctive whitish-grey, of medium- coarse-grain size with dark smoky to almost black quartz and often contain topaz, which is lacking in other types of sheets (Nex, 1997). Uraninite is dominant with traces of brannerite and betafite hosting $<0.3 \%$ of uranium. Significant secondary coffinite and uranophane occurs in surface samples.

In October 2010, Perth-based Bannerman Resources Ltd. announced measured and indicated resources of 57,330 tU at about $0.019 \%$ and inferred resources of 24,600 tU at slightly lower grades, both with 100 ppm cut-off (JORC \& NI 43-101 compliant) for the Etango project, mostly for the adjacent Ondjamba orebodies (Fig. $7 \mathrm{~b}$ ). The alaskite ore has been proved to a depth of $400 \mathrm{~m}$, but as two thirds of the resource is $<200 \mathrm{~m}$ deep, open pit mining is possible

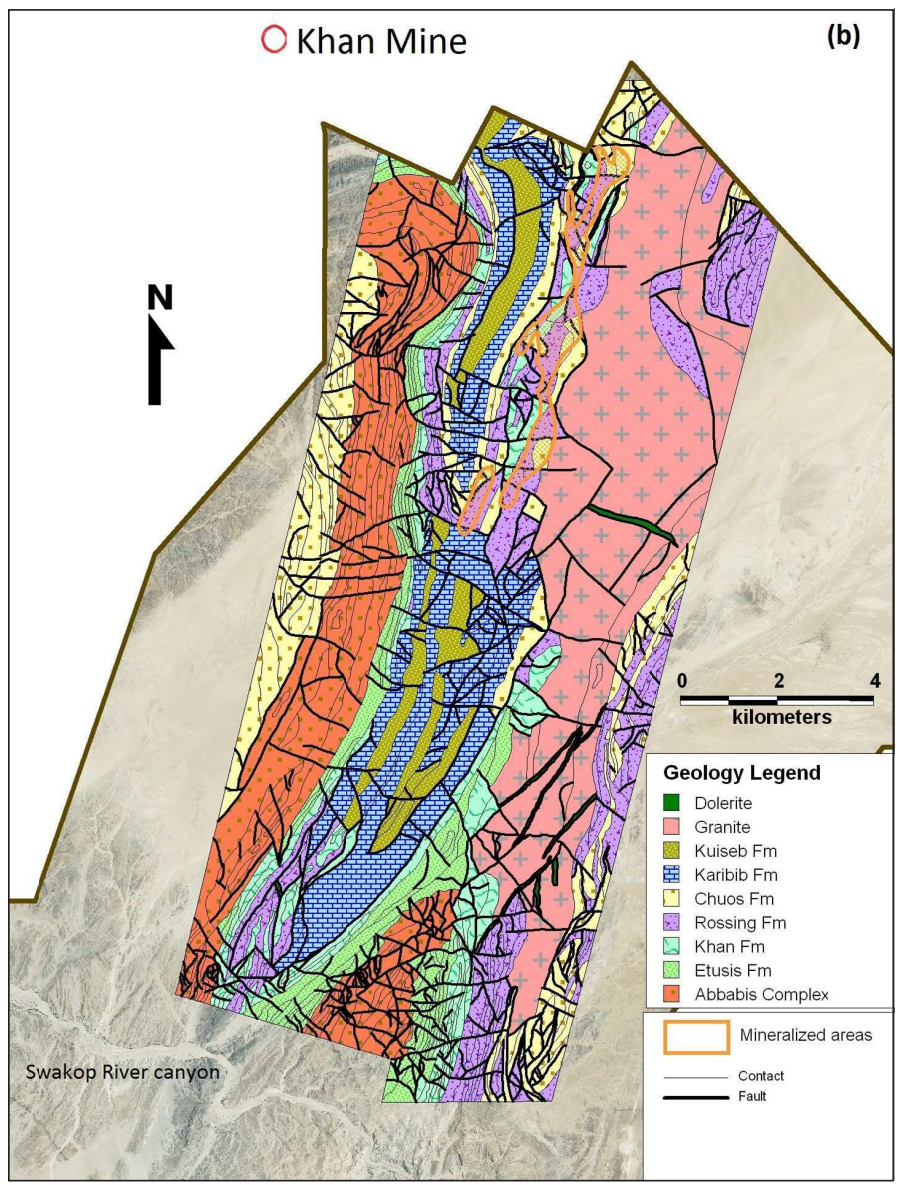

with heap leaching the most cost-effective recovery method (WNA, March 2015). A production of 2,700 tU/yr is envisaged and a heap leach demonstration plant was under construction to demonstrate the viability of the operation.

\section{Norasa (Valencia and Namibplaas)}

The Valencia deposit lies $25 \mathrm{~km}$ northeast of Rössing (Fig. 2). Leucogranite sheets occur predominantly in the Khan Formation but have also intruded up into the Karibib Formation (Fig. 3) and the main body appears to be a coalescence of multiple sheets in the core of a kink fold (Fig. 8a). Mineralised Type D leucogranites are homogeneous medium- to coarse-grained and white to cream in colour, with smoky quartz and often minor accessory biotite entrained at contact margins with gneisses. Uraninite forms $\sim 93 \%$ of all the uranium-rich phases with less than $6 \%$ of the uranium hosted by yellow secondary uranium silicates, uranophane and uranothallite. Namibplaas, $7 \mathrm{~km}$ northeast of Valencia has similar geology. A mining licence was granted in August 2014. Reserves are shown in Table 3. The planned open pit at Valencia will be $1.6 \times 1 \mathrm{~km}$ in extent and 450 $\mathrm{m}$ deep. The Namibplaas pit will be $1.9 \times 0.5 \mathrm{~km}$ in extent and $210 \mathrm{~m}$ deep.

\section{Omaholo}

The Omaholo prospect, situated immediately to the southwest of Ida Dome (Fig. 2), incorporates uraniferous pods and irregularly shaped bodies of E-type leucogranites (Table 2), preferentially located at the boundary between the Khan Formation schist and Rössing 

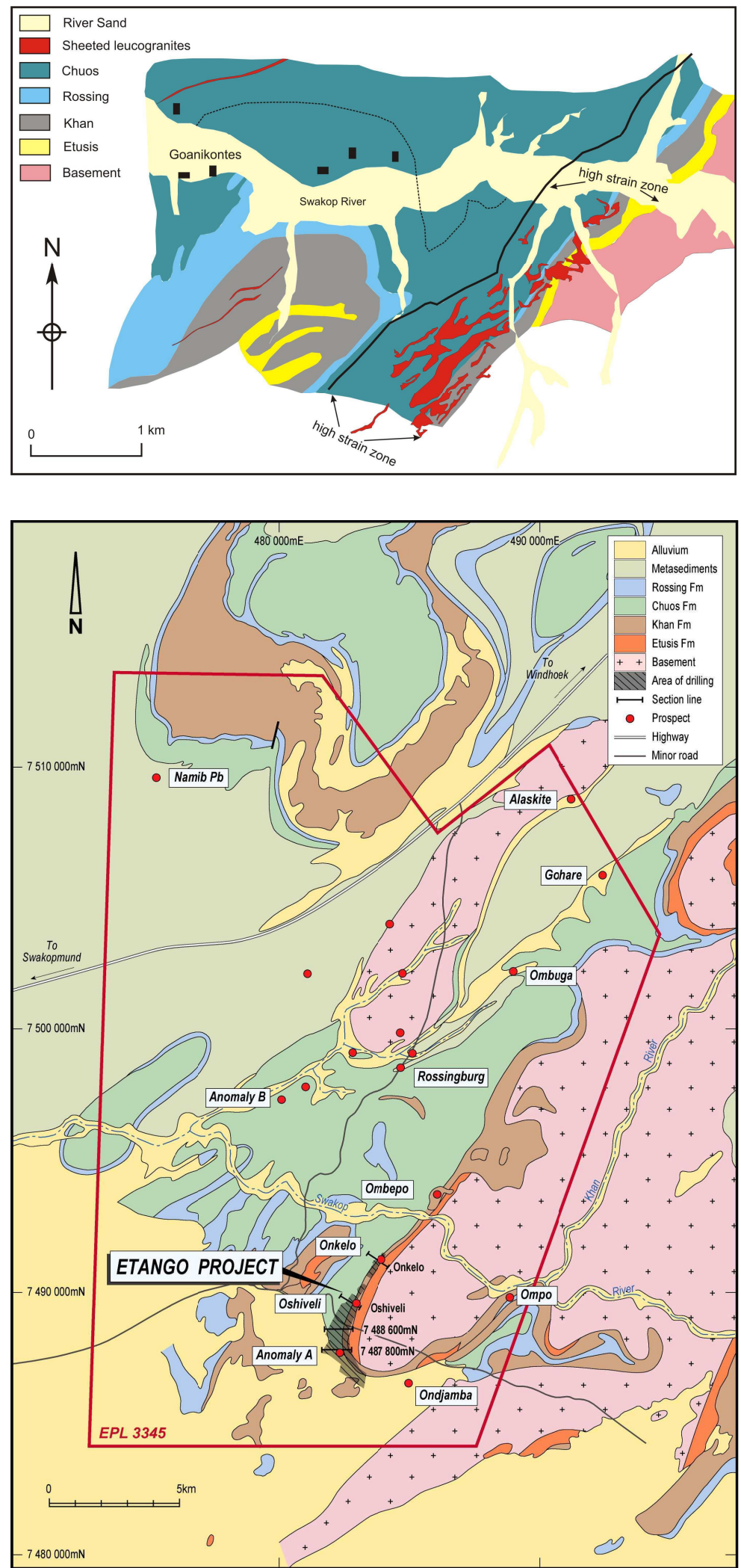

Fig. 7. The Etango project of the Goanikontes area (top) Simplified geological map showing the preferential intrusion of sheeted granites within the high strain zone adjacent to the basement cover contact. The western limit of the high strain zone is shown by a solid black line (after Marlow, 1981; Mouillac et al., 1986; Nex, 1997). The dotted line within the Chuos Fm is a structural form line. (bottom) Simplified regional geological map showing settings of the Etango and other prospects in relation to Rössing.
Formation marble (Fig. 8b). Leucogranites have accessory pyrite, pyrrhotite, chalcopyrite and lesser bornite and molybdenite associated with the uraninite. Reserves shown in Table 3 include a uraniferous magnetite deposit and palaeochannel calcrete-hosted mineralisation.

\section{Other intrusion-related deposits}

At the Palabora carbonatite-hosted copper deposit in South Africa, extraction of uranium began from slurries in 1951. More than 600 tonnes $\mathrm{U}_{3} \mathrm{O}_{8}$ were produced per year until the mid 1990s. When mining went underground in 2004 the uranium was no longer produced. In Mauritania exploration has identified uranium mineralisation in the Bir En Nar area associated with major northwest-southeasterly crustal shearing in syenites, and also in granites near Bir Moghrein and Bir En Nar, in the north of the country (Forte Energy).

\section{Sandstone-hosted roll-front and tabular deposits}

Sandstone-hosted uranium deposits are of diageneticepigenetic, low temperature origin and occur in arid to semiarid environments. Tabular deposits form irregularly-shaped elongate bodies extending along a channel, sometimes stacked to form a significant accumulation of uranium ores. Roll-front deposits form arcuate zones that are convex down the hydraulic gradient. In these deposits, uranium was eroded from source rocks and transported in the hexavalent state in low concentrations in solution and is commonly complexed with carbonate ions which were important for enhancing the solubility and mobility of the uranyl ion in the form of carbonate or other complexes in neutral or alkaline groundwater (IAEA, 2009). The source for the uranium in Niger is widely regarded as the volcanic rocks of alkaline ring complexes (Bigotte and Obeilianne, 1968; Brunnschweiler, 1974; Bowden et al., 1981), whereas in Namibia it is believed to have been late Proterozoic Damaran granites and sheeted leucogranites. These hexavalent uranium-bearing fluids were reduced to the tetravalent state to form commercially important concentrations of pitchblende or coffinite (IAEA, 2009). The reductant varied at different deposits but may have included woody fragments, coalified organic material, structureless organic matter, oils, natural gas, $\mathrm{H}_{2} \mathrm{~S}$, sulphides or even bacterial activity (IAEA, 2009). Uranium deposition depended on host rock permeability and the presence of a reductant. In contrast, at Langer Heinrich and Klein Trekkopje in Namibia, uranium mineralisation formed in an oxidising environment, as uranyl vanadates.

In Africa, grades of these deposits range from $0.10-0.5 \%$ and locally up to $1 \%$ or more. Individual deposits can contain several hundreds of tonnes with up to 120,000 tonnes of uranium at Imouraren in Niger.

\section{Niger}

Niger is currently the world's 5th largest producer of uranium after Kazakhstan, Canada, Australia and Russia, with an estimated $7.6 \%$ of the world's production in 2013 (WNA, 

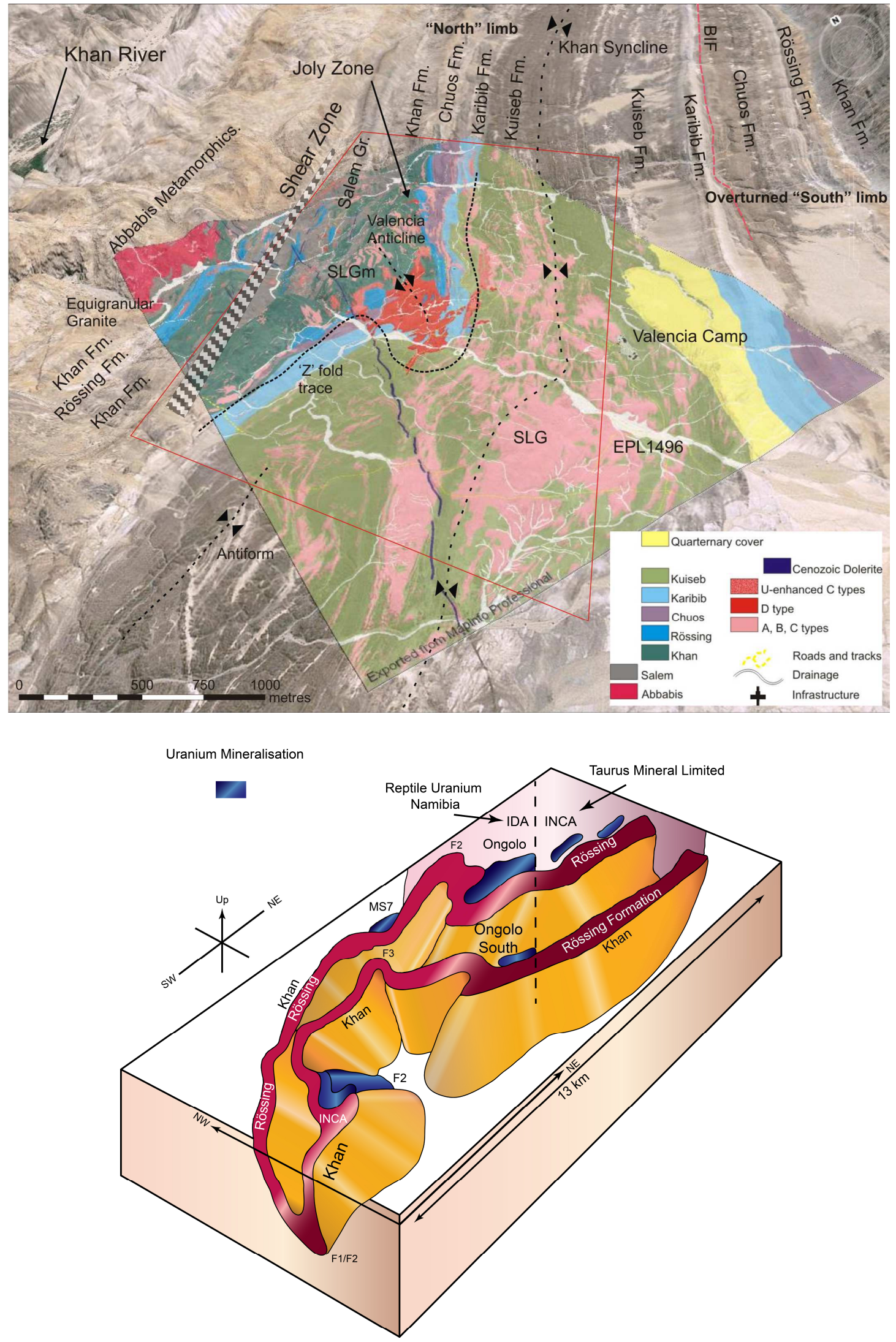

Fig. 8. Geology of granite-hosted uranium deposits (top) Valencia (Freemantle, 2015) The red area within the $Z$ fold represents a massive magnetite-bearing sheeted leucogranite (SLGm) intruded into the core of the fold; (bottom) Omaholo immediately to the southwest of Ida Dome shows a large-scale fold structure. Folds at Ongolo plunge southwest, whilst those at Inca plunge to the northeast. The area between Inca and Ongolo is buckled by north-northeast to south-southwesterly trending folds with steep axes. The red unit is the Rössing Formation (re-drawn from the Deep Yellow website). 
October 2014) but at its peak in the 1980s, $40 \%$ of world uranium output came from the Arlit deposit. The uranium occurs in roll-front deposits at Akouta and in tabular deposits varying in age from Carboniferous at Madaouela, Ebala, Akouta, Arlit, Ariege and Artois, to Jurassic at Imouraren, and Cretaceous at Takardait and Azelik (Cazoulat, 1985). In 2013 Niger produced 4,518 tU, with cumulative production of $114,346 \mathrm{tU}$ to the end of 2010 , some $62,000 \mathrm{tU}$ of this having come from underground mining and 52,000 tU from open pit mining (WNA, October 2014). The uranium concentrates are trucked to ports in Benin for export. There is strong government support for expanding uranium mining but the impact of the mining industry on the local environment has been criticised by African and European non-Governmental organisations, which are particularly concerned about the disregard for health and environmental conditions in the vicinity of the mining operations. There have also been issues with government taxes and Areva's SOMAIR and COMINAK operations were closed for maintenance in December 2013, pending license renewal, but re-opened in early 2014 following an agreement with government on royalties (WNA March, 2015).

The geology of central Niger is dominated by the crystalline massif of the Aïr which is a horst block of Precambrian metamorphic rocks and calc-alkaline intrusives, intruded by more than a dozen Palaeozoic (gabbro)-syenite-granite ring complexes (Bowden et al., 1981). Palaeozoic sedimentary basins to the west of the Air developed in response to repeated movements along ancient northeastsouthwesterly or northwest-southeasterly lineaments. Throughout the
Mesozoic era the uplifted massif was subjected to erosion by intermittent streams to form the continental arkosic sandstones, siltstones, shales, and conglomerates of the Tim Mersoi basin and the more southerly In Gall basin.

A location map of major uranium deposits is shown in Fig. 9a and a schematic stratigraphic column for the region is presented in Fig. 9b. The main uranium deposits of Niger resulted from the complex interplay between palaeogeographic, tectonic and lithostratigraphic factors and the movement of meteoric water that introduced uranium in fluviatile or deltaic sediments during deposition or early diagenesis, although later re-mobilisation concentrated ore, particularly in synforms (Cazoulat, 1985). Uranium mineralisation was discovered at Azelik in 1957 but the most significant uranium occurrence was found at Arlit in 1965, in a lower Carboniferous deltaic series of alternating shales and sandstones (Bigotte and Molinas, 1973). Since then, economic uranium deposits have been discovered within several formations.

\section{Carboniferous deposits in the Guezouman Formation - Akouta, Akola, Afasto/Ebba}

The Guezouman Formation (Fig. 9b) mainly consists of fluviodeltaic fine- to medium-grained sandstones of probable Visean age (Cazoulat, 1985; Turpin et al., 1991). The Akouta deposits were mainly controlled by basement structures (Cazoulat, 1985). Mineralisation at Akouta is elongated across a channel and along a
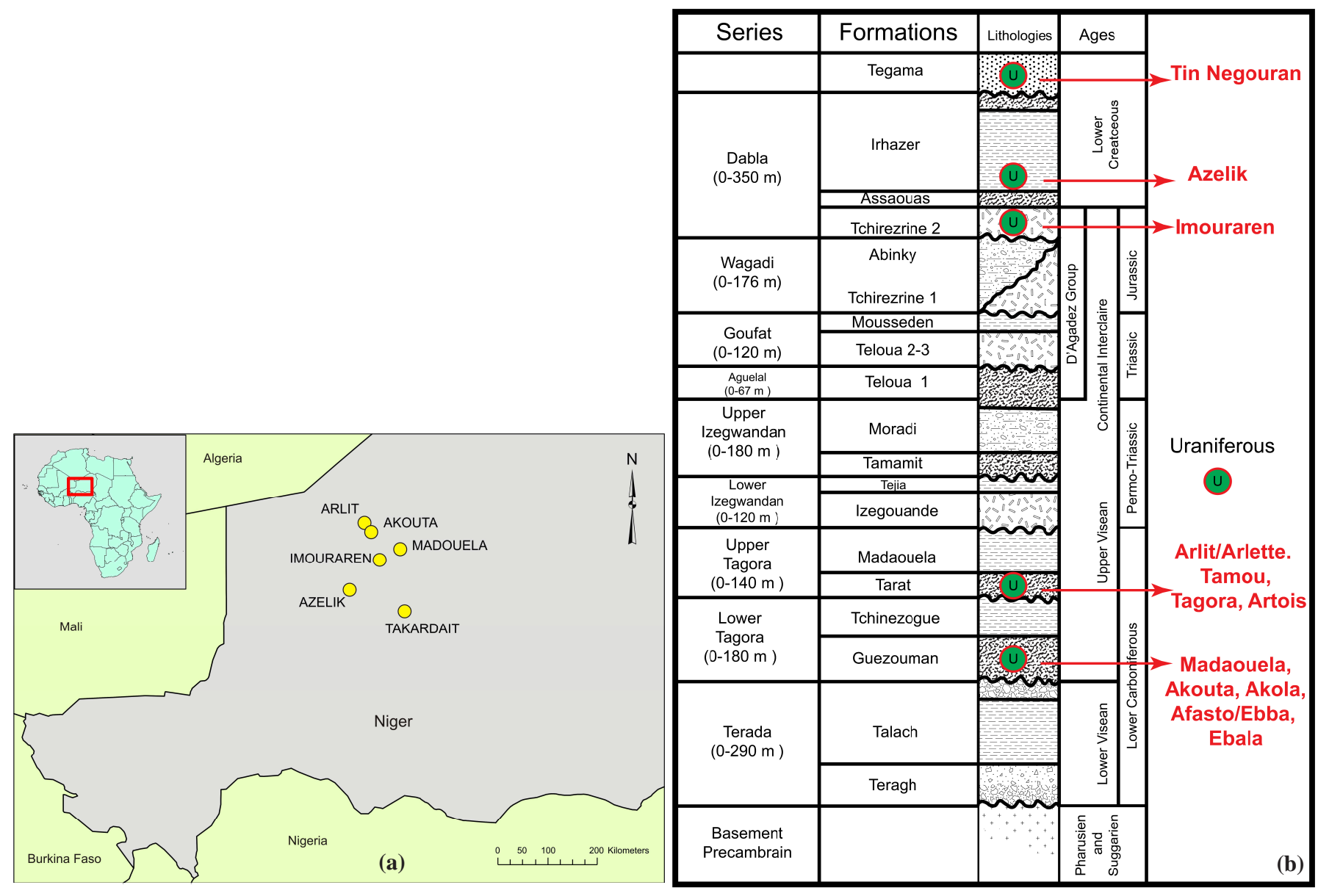

Fig. 9. Location of major sandstone-hosted uranium deposits in west central Niger (a) geographic location (b) stratigraphic host (based on Cazoulat, 1985 and Turpin et al., 1991). 
syncline and is in part a roll-front and in part a tabular deposit. It comprises massive pitchblende concentrations, from a few to several tens of centimetres in size, in bottom-set layers and along basal foresets and also as pitchblende cementation of sandstone (Turpin et al., 1991). Cazoulat, (1985) described pitchblende or coffinite as dominating. The mineralogy comprises pyrite, marcasite, sphalerite, galena, montroseite, vanadiferous chlorite, corrensite $(\mathrm{Mg}, \mathrm{Fe})_{9}$ $\left.(\mathrm{Si}, \mathrm{Al})_{8} \mathrm{O}_{20}\right)(\mathrm{OH})_{10} \mathrm{nH}_{2} \mathrm{O}$ and jordisite $\left(\mathrm{MoS}_{2}\right)$ (Cazoulat, 1985; Turpin et al., 1991). Fluid-inclusions in sphalerite indicate that temperatures as high as $160^{\circ} \mathrm{C}$ were reached within the deposit (Turpin et al., 1991) and lead isotopic dating gave an age of $338 \pm 5 \mathrm{Ma}$ (Cazoulat, 1985).

The Compagnie Minière d'Akouta (COMINAK) founded in 1974, started production from Akouta in 1978, and then from the Akola and Afasto deposits. Ore is mined from underground operations at a depth of $\sim 250 \mathrm{~m}$, and the orebody is accessed by $250 \mathrm{~km}$ of tunnels (WNA, March 2015). With a mill capacity of 2,000 t/yr of magnesium uranate, the production in 2006 was $1,870 \mathrm{tU}$ from $0.45-0.55 \%$ ore. Production declined to $1,506 \mathrm{tU}$ in 2012 from a grade of $0.4 \% \mathrm{U}$. Resources at end 2013 are shown in Table 5. Production is currently switching to the new deposit of Ebba/Afasto, south of Akouta and Akola.

\section{Carboniferous deposits in the Tarat Formation - Arlit/Arlette, Tamou, Tagora, Artois, Lixi}

The Tarat Formation, of probable Visean age, is a medium- to very coarse-grained sandstone $\sim 9-55 \mathrm{~m}$ thick, with intercalated black siltstones and shales rich in organic matter (Cazoulat, 1985; Turpin et al., 1991). Arlit and Akokan are twin mining towns of the company SOMAIR (Société des Mines de l' Aïr). They are located to the west of the Air Mountains, 1,200 km to the northeast of Niamey (WNA, March 2015). Uranium deposition was strongly controlled by basement faults and was penecontemporaneous with sediment deposition where organic matter was abundant, forming stratiform ore bodies. Later re-mobilisation of ore during diagenesis resulted in predominantly stratabound bodies with local roll-front structures. Mineralisation is widely distributed within siltstones and shales but pervades sandstones such as that in the Arlette body, where mineralised sandstone less than $20 \mathrm{~m}$ thick has been reported (Cazoulat, 1985). High-grade ore is composed principally of microscopic pitchblende and coffinite in equal proportions, associated with pyrite and/or marcasite coating quartz grains in the sandstones. In the very high-grade ore, uranium minerals completely cement the sandstones. In the oxidised zones, as at Ariette, tyuyamunite, francevillite and carnotite occur in association with iron oxides or kaolinite. Sphalerite and galena are often associated with traces of vanadium (V) and molybdenum (Mo) (Cazoulat, 1985).

SOMAIR was formed in 1968 to mine the Arlette/Arlit deposit. Production began in 1971, from open pit mining to a depth of $60 \mathrm{~m}$, at a grade of $0.30-0.35 \%$ ore. By 1981, the company was producing $2,100 \mathrm{tU} / \mathrm{yr}$ and by $20061,565 \mathrm{tU} / \mathrm{yr}$ from the Tamou deposit. The production peaked at $3,065 \mathrm{tU}$ in 2012 before dropping in 2013 due to terrorist sabotage. The Artois deposit is deeper $(90 \mathrm{~m})$ and at a lower grade (0.20-0.25\%). Indicated resources are reported as 37,027 $\mathrm{tU}$, as of 2013 , at a grade of $0.132 \%$. A new $1.4 \mathrm{Mt}$ per year heapleach operation for low-grade ore $(<0.1 \% \mathrm{U})$ has contributed up to $1,000 \mathrm{tU} / \mathrm{yr}$ to production since 2010 .
Table 5. Uranium production in tonnes (WNA, March 2015)

\begin{tabular}{|l|l|l|l|l|l|}
\hline & 2009 & 2010 & 2011 & 2012 & 2013 \\
\hline SOMAIR & 1,808 & & 2,726 & 3,065 & 2,730 \\
\hline COMINAK & 1,435 & & 1,075 & 1,506 & 1,508 \\
\hline SOMINA & & & 64 est & 96 est & 290 est \\
\hline Total & & & 3,865 & 4,667 & 4,528 \\
\hline
\end{tabular}

\section{Jurassic deposits in the Tchirezrine Formation - Imouraren}

The Tchirezrine sandstones host the Imouraren deposit with hexavalent uranium minerals, and abundant $\mathrm{Cu}$ (Turpin et al., 1991). Areva was granted an exploration licence in 2006 for the Imouraren mine, located about $80 \mathrm{~km}$ south of Arlit, the ore body being originally discovered in 1969. By 2006 more than $55 \mathrm{~km}$ of development drilling and bulk sampling had been completed and mining permission was obtained in 2009, with the operational launch conducted in 2010. The mine was anticipated to have the largest uranium reserves in Niger (120,000 tonnes) albeit at a lower concentration of uranium $\left(\mathrm{U}_{3} \mathrm{O}_{8}\right.$ at $0.15 \%$; OECD, 2009). The deposit covers $8 \times 2.5 \mathrm{~km}$ and is located at an average depth of $110 \mathrm{~m}$ with a maximum thickness of $60 \mathrm{~m}$. Areva state a reserve of 213,700 tonnes of contained uranium at $0.07 \% \mathrm{U}$, plus $62,500 \mathrm{tU}$ within indicated resources. Areva was aiming for initial production in 2014, ramping up to 5,000 tU/yr for 35 years, which would have made the deposit the largest mining project ever undertaken in Niger, the largest open pit uranium mine in Africa, and the largest anywhere to use heap leaching on a 42 hectare pad. However, in 2014, Areva and the Niger government delayed development pending favourable market conditions.

\section{Lower Cretaceous deposits - Azelik and Abokorum}

SOMINA (Société des Mines d'Azelik SA) was established in 2007 to mine the Azelik/Teguidda deposit, $160 \mathrm{~km}$ southwest of Arlit and $150 \mathrm{~km}$ northwest of Agadez. Azelik is being developed with major CNNC (China National Nuclear Corporation) funding and started production at the end of 2010 (WNA, January 2015). It is an open pit and underground operation using alkaline leach. It is reported to have resources of $15,600 \mathrm{tU}$ at $0.2 \%$. Following prolonged project delays, overruns in construction budget, and low production, CNNC hope to raise production to $2,500 \mathrm{t} / \mathrm{yr}$ by 2015 and double that by 2020.

\section{New mines and prospects}

The World Nuclear Association (January 2015) notes a number of new developments. In 2006 CNNC agreed to develop the 12,790 tU Abokorum deposit in the Agadez region, but no development has occurred yet, probably due to the low uranium price. The Tagaza deposits, $40 \mathrm{~km}$ northwest of Agadez, have also been investigated. The Madaouela Uranium Project has 38,000 tU indicated resources and 9,200 $\mathrm{tU}$ inferred resources. An open pit mine on part of the deposit with conventional processing, is expected to produce $1,000 \mathrm{tU} / \mathrm{yr}$ over 15 years, with potential for expanding the resource. 


\section{Malawi}

Kayelekera in northern Malawi (Fig. 10), is one of the largest Karoo age sandstone hosted uranium deposits. It is associated with Permian Karoo sediments and is hosted by the Kayelekera member of the North Rukuru sediments. The deposit occurs as stacked, sandstone-hosted lenses (Fig. 11). The mineralisation is associated with seven variably oxidised, coarse-grained arkoses with up to $25 \%$ muscovite and biotite, separated by shales and chocolate coloured mudstones and is associated with organics, pyrite and chlorite (Bowden and Shaw, 2007). Three ore types are recognised: reduced facies ore, oxidised facies ore and transitional facies ore containing both oxidised and reduced facies ore in varying proportions. Because it is more mobile under oxidising conditions, uranium tends to be leached from the oxidised parts of the deposit and re-deposited in more reducing parts (Bowden and Shaw, 2007). There is a marked disequilibrium between uranium and its daughter elements, with the oxidised facies being depleted in uranium relative to its daughters

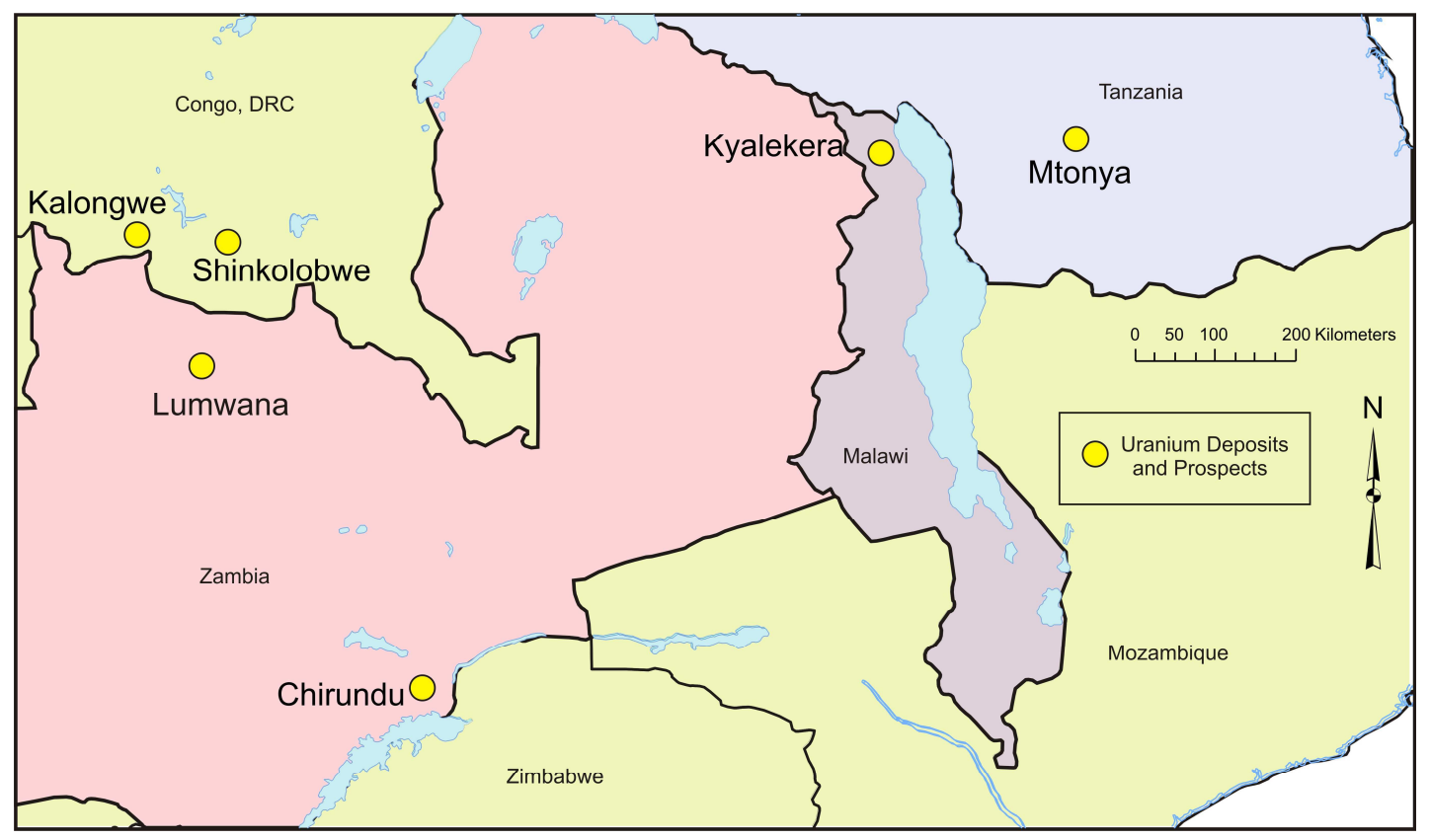

Fig. 10. Location of uranium deposits in East Africa

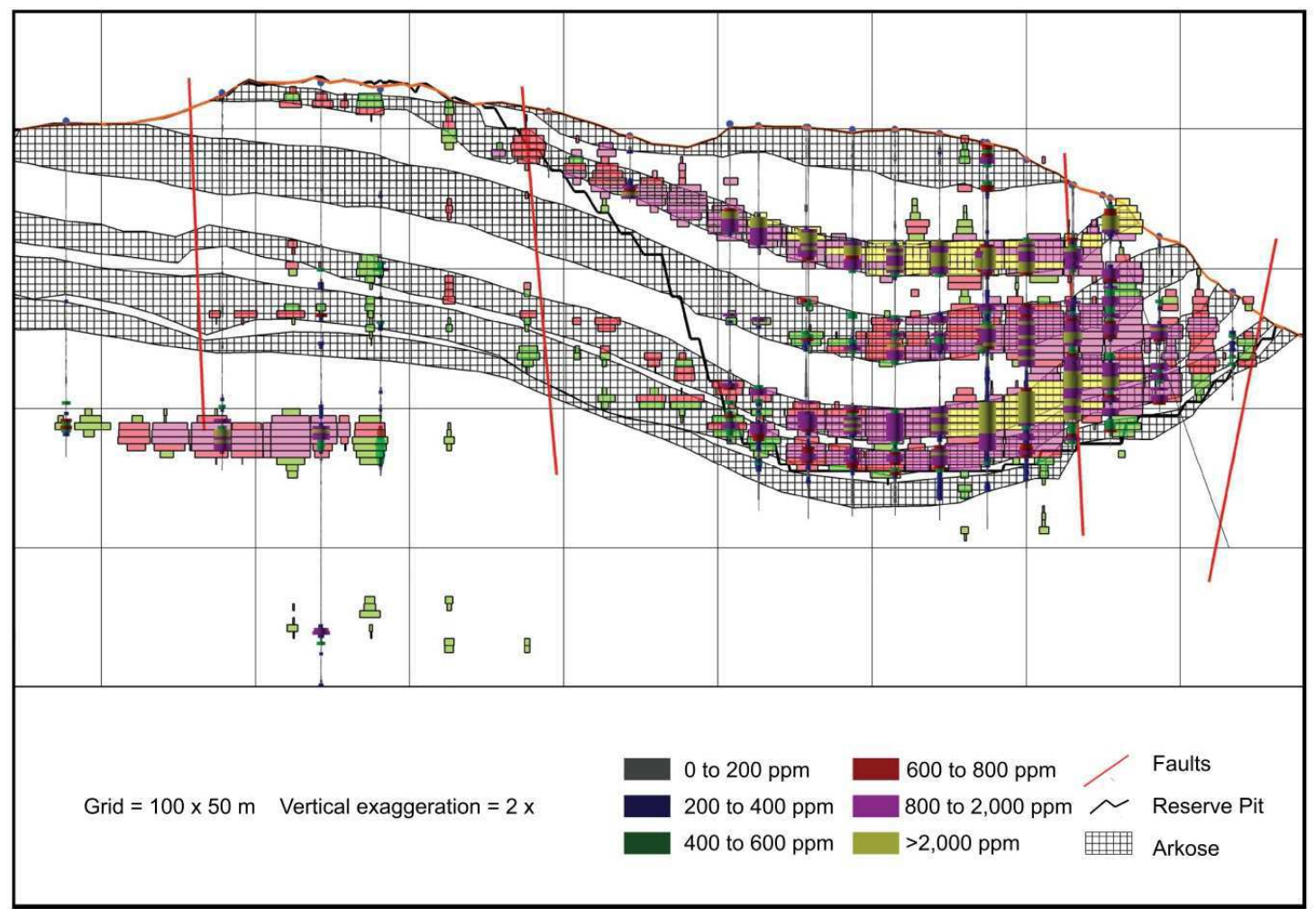

Fig. 11. Cross section of the central pit area of the Kayelekera uranium project, Malawi (Paladin 2015). 
and the reduced facies ore often showing relative enrichment. In the reduced zone coffinite dominates, with lesser uraninite, while in the oxide facies, meta-autunite and boltwoodite dominate, with minor uranophane (Bowden and Shaw, 2007). The lowest level of known mineralisation currently is at a depth of approximately $160 \mathrm{~m}$ below surface (Paladin website). In spite of the high concentrations of acid consuming muscovite and biotite, the Kayelekera deposit is processed by a conventional acid leach (Paladin Energy, 2010).

Kayelekera was discovered by the UK Central Electricity Generating Board (CEGB) in the early 1980s. After an eight year study, culminating in a full feasibility study for open pit mining in 1991, the project was abandoned in 1992 due to the poor outlook for uranium, as well as privatisation of the CEGB. In 1998 Paladin acquired an interest in Kayelekera. Following, a bankable feasibility study in May 2005, resource drilling and bulk sample drilling for metallurgical test work were completed in August 2005 and showed this to be the largest known uranium deposit in the Karoo of southern Africa, with over 15,000 tonnes of $\mathrm{U}_{3} \mathrm{O}_{8}$ in sandstones and mudstones. A Mining Licence for Kayelekera was granted to Paladin in April 2007 and production began in mid-2009, and reached 1,134 tU in 2013, with output expected to ramp up to $1,460 \mathrm{tU} / \mathrm{yr}$. However, in May 2014, due to low uranium prices, Paladin put the mine into care and maintenance until prices exceed US\$75 lb. As of April 2011 reserves were $11,265 \mathrm{tU}$ at $0.04 \%$ cut-off, with $15,000 \mathrm{tU}$ measured and indicated resources at an average of $0.08 \%$ ore (JORC and NI 43-101 compliant). The orebody remains open to the west with exploration on nearby leases, including Mpata to the east and Juma to the south.

\section{South Africa}

In the southwestern part of the large Karoo basin $\left(\sim 700,000 \mathrm{~km}^{2}\right)$ of South Africa (Fig. 1), uranium mineralisation occurs in fluvial sandstone-hosted tabular bodies in the Beaufort Group (Le Roux, 1993), often adjacent to organic mudstones or shales, or where there are organic remains in pockets in the sandstones. These were discovered by Union Carbide in 1969, $20 \mathrm{~km}$ west of Beaufort West. The ore bodies are normally about $1 \mathrm{~m}$ thick, and rarely up to $7 \mathrm{~m}$, but where stacked reach $20 \mathrm{~m}$ in thickness and extend for several hundreds of metres in length and $200 \mathrm{~m}$ in width along palaeochannels (Cole et al., 1991). Typically, the host is a variably-cemented very fine immature arkosic sandstone, with plagioclase and potassiumfeldspar altered to zeolite, chlorite, sericitic muscovite and calcite, accompanied by detrital biotite and muscovite (Youlton, 2014). Carbon is abundant in the more uranium-rich portions of the sandstones and it is envisaged that uranium was precipitated in isolated reduced zones with plant and algal matter (Turner, 1985; le Roux, 1993). Uranium was derived mainly from volcanic detritus and interbedded mudstones (Cole, 1998) and is dominantly in the minerals coffinite and lesser uraninite and mainly occurs at the base of thicker, more permeable palaeo-channels (Turner, 1985). Associated ore minerals include pyrite, molybdenite, arsenopyrite and chalcopyrite (Turner, 1985; Youlton and Kinnaird, 2013). There is also a weak relationship between uranium and calcite (which is typically present in concentrations of about 10\%), suggesting some ore may have been deposited from uranyl carbonates (Turner, 1985). Total resources have been estimated at 31,000 tU (NEA.IAEA, 1994). The largest deposit Ryst Kuil, $45 \mathrm{~km}$ southeast of Beaufort West was discovered by Esso in the 1970s and re-evaluated during times of higher uranium price, with 19,000 tonnes $\mathrm{U}_{3} \mathrm{O}_{8}$ resources $(16,000 \mathrm{tU})$ estimated on an historic basis at $0.1 \%$ grade, with more recent drilling to convert historical resource information to JORC-compliance (WNA, March 2015). Mine production of 1,350 tonnes $\mathrm{U}_{3} \mathrm{O}_{8}$ per year was projected by the end of 2009 but this has been delayed (WNA, October 2014). Most deposits such as Mooifontein, Rietkuil and Drie Vaderlandsche contain less than $1,000 \mathrm{tU}$. Overall grade in all cases is typically only $0.10 \% \mathrm{U}_{3} \mathrm{O}_{8}$, sometimes with molybdenite as a by-product (Cole, 1998). Grade variation is considerable and the continuity of the deposits is difficult to establish, which is perhaps the most significant challenge towards exploitation.

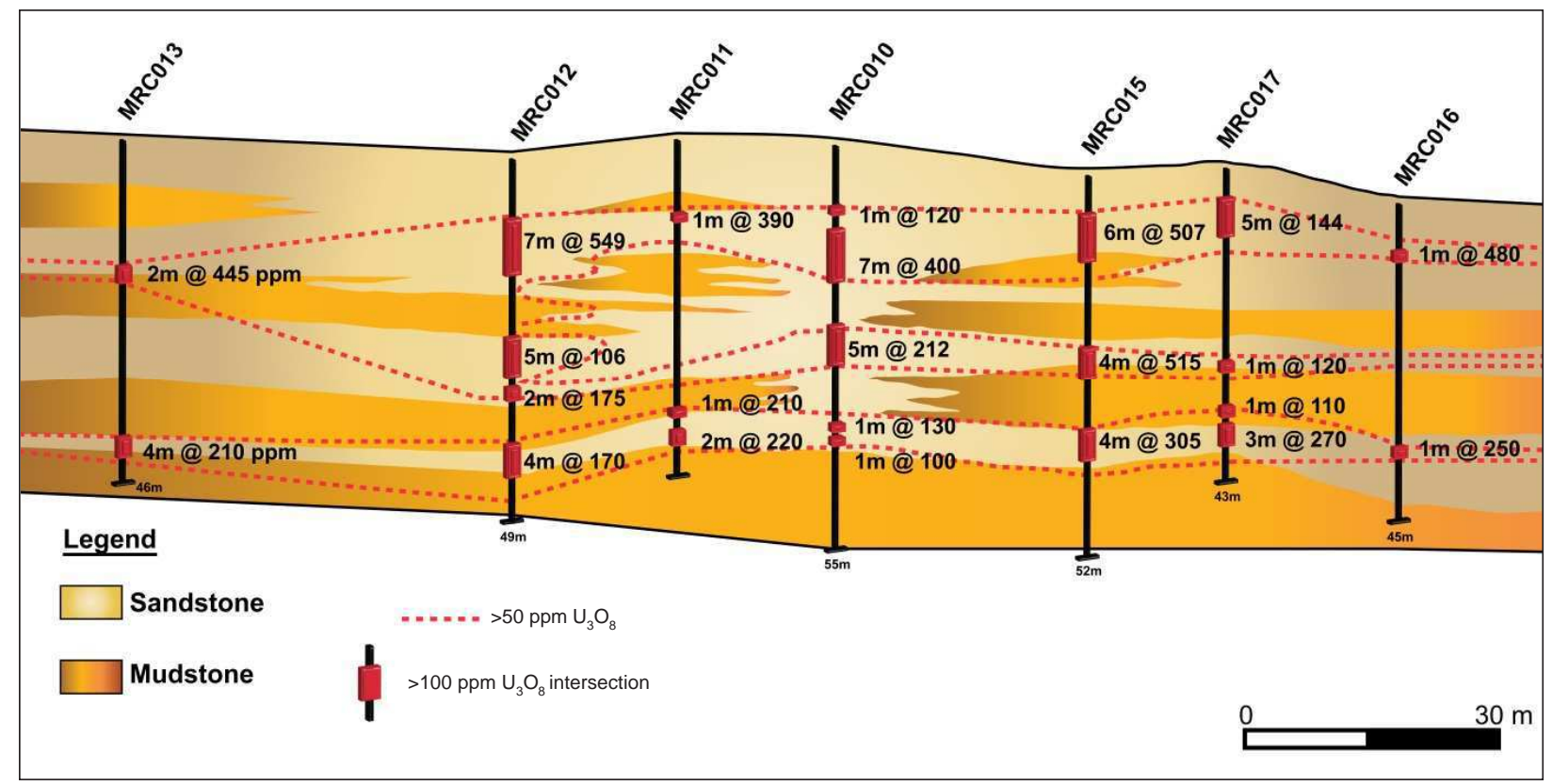

Fig. 12. Cross section of the Mtonya project from Western Minerals website. Oblique section facing north. 


\section{Gabon}

Sandstone-hosted tabular uranium deposits, dominantly in fluvial sandstones of Palaeoproterozoic age in the Franceville Basin, host pitchblende within an organic matrix along the margins of palaeochannels. Tabular deposits are $<900 \mathrm{~m}$ long and $600 \mathrm{~m}$ wide and several metres thick, and contain $<13,000 \mathrm{Mt}_{3} \mathrm{O}_{8}$ at a grade of $\sim 0.4 \%$ (Dahlkamp, 1993). Some deposits have been tectonised, such as at Mikouloungou and Mounana and these may be up to $100 \mathrm{~m}$ long, $40 \mathrm{~m}$ wide, $120 \mathrm{~m}$ deep with a grade of $0.2-0.6 \% \mathrm{U}_{3} \mathrm{O}_{8}$. The Mounana uranium deposits in the southeast of the country were discovered in 1956 by French Atomic Energy Commission geologists. Mining began from an open pit (1960-75), then went underground producing nearly $28,000 \mathrm{tU}$. Oklo began as an open pit (1970-85), then went underground and produced over 14,000 tU. Operations closed in mid- 1999 due to a lack of economically recoverable reserves. Boyindzi was active between 1980 and 1991, while the Mikouloungou open pit produced ore between 1997 and 1999. Grade was typically around $0.37 \%$. At the end of 2013 Areva quoted 5,420 $\mathrm{tU}$ at $0.027 \%$ inferred resources at the Bagombé deposit. No current uranium mining occurs in Gabon but exploration continues.

The country is noted for its natural nuclear reactor, which was discovered in the early 1970s, when French geologists investigated a uranium deposit at Oklo. They discovered that in some places, the proportions of different isotopes of uranium differed from those usually found in nature. Normally the heavier isotope ${ }^{238} U$ is approximately 139 times more common than the lighter and fissionable ${ }^{235} \mathrm{U}$. But at Oklo, the lighter isotope is much rarer than normal. It was realised that a natural nuclear fission reactor with self-sustaining nuclear chain reactions had occurred. At Oklo, sixteen sites have been discovered where self-sustaining nuclear fission reactions took place $\sim 1.7 \mathrm{Ga}$ ago. These are believed to have run for a few hundred thousand years, averaging $100 \mathrm{~kW}$ of thermal power during that time (Meshik, 2005). All reactors have been found on sites where a layer of uranium-bearing sandstone is in contact with an overlying layer of clay shale. In the boundary zone, uranium slowly concentrated as oxygen-rich uranium-bearing groundwater seeped up into the sandstone from below. With sufficient uranium enrichment, a nuclear reaction became self-sustaining, as in a nuclear power plant. The reactor worked on a 30-minute reaction cycle, followed by a twoand-a-half hour cool down. Investigations in the surrounding area show that the resultant plutonium has not moved very far, as it was bound to mineral grains in the rock almost immediately. Thus this natural system not only went critical, it also safely stored the waste. Today even the largest and richest uranium deposit cannot become a natural reactor because the present concentration of ${ }^{235} \mathrm{U}$ is too low at only about $0.72 \%$. However, because ${ }^{235} \mathrm{U}$ decays much faster than ${ }^{238} \mathrm{U}, 2$ billion years ago ${ }^{235} \mathrm{U}$ concentrations were five times higher at about $3 \%$ of total uranium, approximately the concentration of enriched uranium used in modern reactors. The uranium mines at Oklo and Okélobondo are now abandoned. The reactor zones were partially destroyed when the ore around them was mined. Today, only the natural reactor at Bagombé remains.

\section{Tanzania}

Several companies have been exploring a number of roll-front type deposits in Karoo sandstones in the southwest of the country to the east of the large Kayelakera deposit in Malawi. These roll front deposits are hosted in river channels and have a convex shape facing downstream. The Mtonya Project (Fig. 10 and 12) occurs at the contact between the Usagaran basement source and Luwegu basins, with porous Karoo sandstones hosting roll-front deposits. The best drilling intersection recorded is given as $7 \mathrm{~m}$ at $1,233 \mathrm{ppm} \mathrm{U}_{3} \mathrm{O}_{8}$ with inferred resources of $770 \mathrm{tU}$ (Western Metals of Australia). The Mkuju River project, $470 \mathrm{~km}$ southwest of Dar es Salaam, in the Namtumbo district of southern Tanzania and $55 \mathrm{~km}$ north of Mtonya, incorporates the Nyota deposit. The government has allocated $345 \mathrm{kms}^{2}$ of land inside the $50,000 \mathrm{kms}^{2}$ world heritage Selous Game Reserve to the project. Uranium One is expected to start mining in 2013, eventually producing 1,400 tU/yr, but has deferred the project. Resources are $58,620 \mathrm{tU}$, comprising measured and indicated resources of 48,000 $\mathrm{tU}$ and inferred resources of 10,620 $\mathrm{tU}$ with an average grade of $0.026 \%$ uranium at $100 \mathrm{ppm}$ cut-off (March, 2013). A preliminary

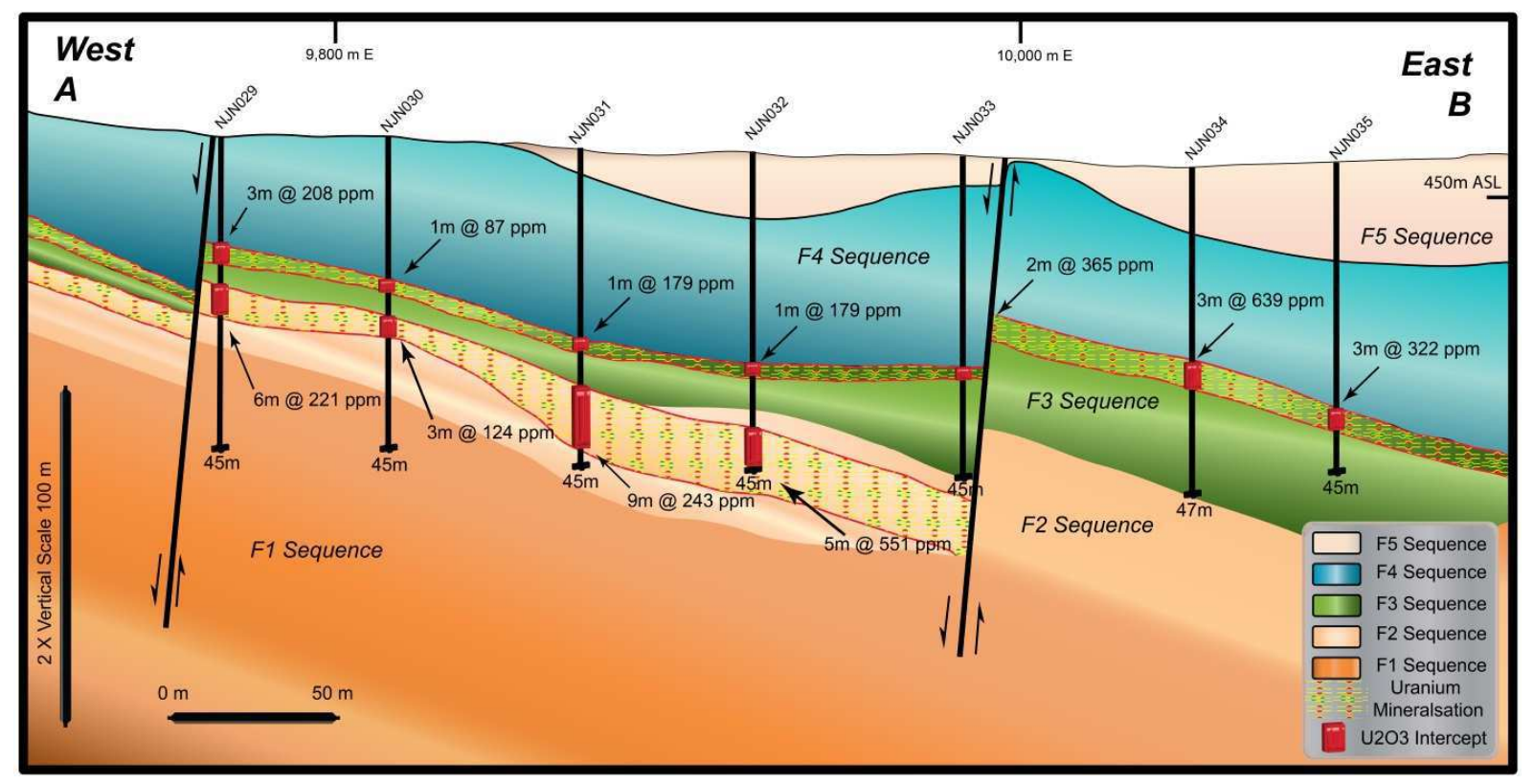

Fig. 13. Cross-section of the Karoo sandstone-hosted deposits of the Chirundu (Njame-North) prospect at Chirundu. 
feasibility study on heap leaching lower grade ore, as phase 2 of the project, is currently underway. In central Tanzania, $80 \mathrm{~km}$ west of Dodoma, inferred resources of 5,885 tU have been reported in a shallow deposit at Manyoni (www.wise-uranium.org Mar 2015).

\section{Zambia and Zimbabwe}

Thick upper Karoo sediments occur in the Kariba and LuanoLuangwa Valleys. At Chirundu (Njame North) (Fig. 10), uranium mineralisation occurs near surface in two layers, the lower-most being thicker and of higher grade, with overburden of $5 \mathrm{~m}$ to $34 \mathrm{~m}$ (Fig. 13). The deposit is open along strike and down dip and is hosted by the 'escarpment grits' which are similar in age to the sediments hosting uranium in Malawi. African Eagle Resource has declared resources of 5,035 tonnes $\mathrm{U}_{3} \mathrm{O}_{8}$ at their Chirundu and Kariba Valley projects.

\section{Surficial uranium deposits}

In Africa, surficial deposits are characterised by fairly recent accumulations of uranium in stratabound, generally surficial sediments proximal to uraniferous source rocks, generally in arid environments. The sediments may have been consolidated by carbonates, calcrete, gypcrete or sulphates without any organic matter. They comprise about $4 \%$ of world uranium resources with excellent examples of this type of deposit occurring in palaeo-channels in Namibia. These sediments formed within the last $60 \mathrm{Ma}$ as near-surface valley-fill sands and gravels in semi-arid to arid areas. Carnotite occurs with quartz, feldspar, mica, palygorskite, calcite, gypsum and halite.

\section{Namibia}

Surficial uranium deposits in Namibia occur in the Namib Desert, between the Great Escarpment in the east and to within $50 \mathrm{~km}$ from the Atlantic coast, a region that falls in the $100 \mathrm{~mm}$ isohyet. The deposits are hosted by typically coarse fluvial sediments within palaeo-valleys of ancient rivers that flowed westwards from the Great Escarpment during Upper Cretaceous and Lower Tertiary times, but now remain largely as dry valleys with a sub-surface flow. The Namib Desert is extremely arid, which has promoted the preservation of deposits, mainly as carnotite coatings on mineral grains and in cavities in conglomeratic layers. There are two main economic deposits, Langer Heinrich and Trekkopje. Because of the high concentrations of reactive gangue with typically $\sim 17 \%$ calcite, both
Langer Heinrich (Venter and Boylett, 2009) and Trekkopje (Faurie, 2010), use an alkali leach in processing.

\section{Langer Heinrich}

Paladin's Langer Heinrich deposit is $50 \mathrm{~km}$ south-southeast of Rössing, in the Namib-Naukluft National Park, and $90 \mathrm{~km}$ east of Swakopmund in the Gawib River valley (Fig. 2). Carnotite was first discovered here in the late 1950s. The prospect was bought by Paladin Resources in 2002. The open pit mine commenced operation late in 2006 with 1,000 tU/yr capacity. In January 2014 CNNC (China National Nuclear Corporation) bought a $25 \%$ stake in the mine.

The Langer Heinrich Formation is comprised of non-calcareous, relatively poorly mineralised brown basal conglomerates, grits, sands and clays which were deposited onto Late Proterozoic biotite-schists and calc-silicates. These basal sediments are unconformably overlain by calcareous breccia, conglomerate, grit and sand that have been cemented by calcrete which hosts the major uranium mineralisation. The detrital minerals and rock fragments in all sediment types are, in decreasing order of abundance: quartz, feldspars, calcite, mica, illite, vermiculite and lithoclasts. Bedrock is of late Proterozoic Damaran Tinkas Formation biotite-schists and calc-silicates.

Mapping of the faces in an open pit at Langer Heinrich suggests that there are at least 7 distinct types of facies exposed from the $\pm 632 \mathrm{~m}$ top surface, to $\pm 612 \mathrm{~m}$ above sea level to which mining has so far taken place. These facies do not occur in any particular sequence, but their alteration is indicative of past cyclic periods of oxidising and reducing conditions.

Uranium mineralisation is enriched in irregularly distributed isolated pockets in a calcrete-hosted palaeo-channel of the Gawib River that is up to $50 \mathrm{~m}$ deep and $15 \mathrm{~km}$ long (Fig. 14) and in overbank deposits around the channel. Uranium was sourced from the Neoproterozoic Bloedkoppie granite over $15 \mathrm{Ma}$ (Iilende, 2012) and possibly also from sheeted leucogranites and pegmatites, while a positive cerium (Ce) anomaly in some samples suggests some of the uranium was sourced from a weathered lateritic profile. Uranium deposition is regarded as probably having occurred during wetter periods in the past (Ward et al., 1983; Hambleton-Jones and Toens, 1978). However, dating of overbank deposits suggested an age of 68,000 years (Fleurance et al., 2011). The uranium ore is a mixture of carnotite and tyuyamunite (Fleurance et al., 2011).

There is a conventional hard rock mill with an alkaline leaching circuit at the mine. From late 2011 plant development boosted

Table 6. Resources for surficial palaeochannel-hosted and aeolian deposits in Namibia (WNA, October 2014).

\begin{tabular}{|l|l|l|l|}
\hline Deposit name & Type & Measured and indicated resources & Inferred resources \\
\hline Langer Heinrich & Palaeochannel & $57,500 \mathrm{tU}$ in $0.055 \%$ ore & $9,200 \mathrm{tU}$ in $0.06 \%$ ore \\
\hline Trekkopje & Palaeochannel & $26,000 \mathrm{tU}$ in $<0.011 \%$ ore & $3,000 \mathrm{tU}$ in $0.01 \%$ ore \\
\hline Marenica & Palaeochannel and hard rock & $2,500 \mathrm{tU}$ in $0.010 \%$ ore & $19,600 \mathrm{tU}$ in $0.008 \%$ ore \\
\hline Tubas-TRS & Aeolian & 0 & $10,900 \mathrm{tU}$ in $0.0125 \%$ ore \\
\hline
\end{tabular}

Table 7. Production from sediment-hosted uranium deposits, in metric tonnes (World Nuclear Authority Sept 2015).

\begin{tabular}{|l|l|l|l|l|l|l|l|}
\hline & 2008 & 2009 & 2010 & 2011 & 2012 & 2013 & 2014 \\
\hline $\begin{array}{l}\text { Langer } \\
\text { Heinrich }\end{array}$ & 919 & 1,108 & 1,419 & 1,437 & 1,960 & 2,098 & 1,914 \\
\hline Trekkopje & 0 & 0 & 0 & 0 & 251 & 186 & $0 ?$ \\
\hline
\end{tabular}



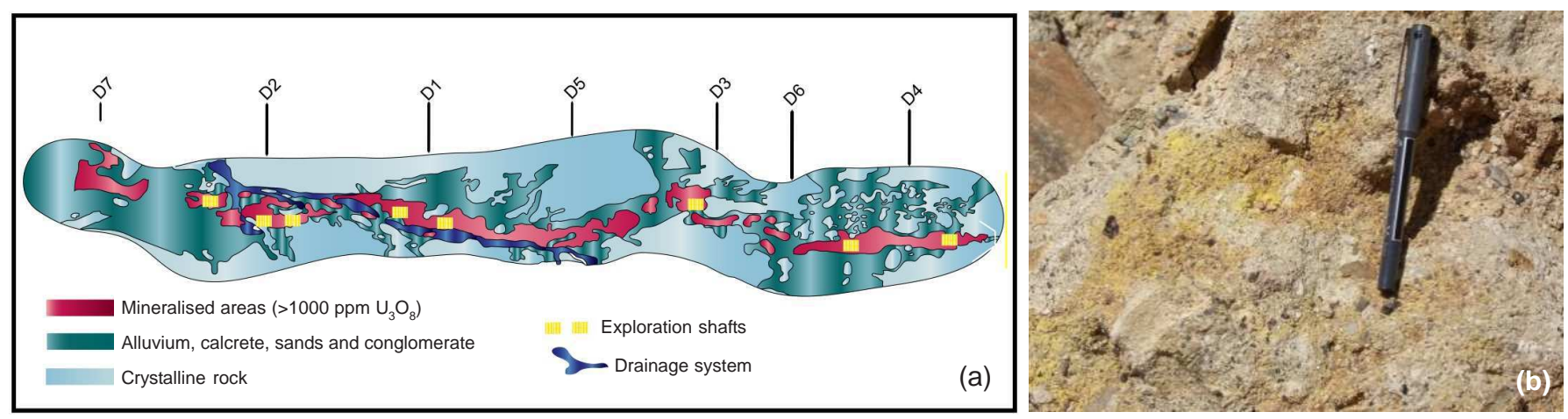

Fig. 14. The Gawib River (a) palaeochannel showing the distribution of uranium mineralised areas from the Paladin visitors guide 2005. (b) visible carnotite in pebbly calcrete

production to 2,000 tU/yr (Tables 6 and 7). In mid-2013 cash costs were US\$ 29.40 / lb. A heap leach to produce about $400 \mathrm{tU} / \mathrm{yr}$ from low-grade ore by mid 2014 was proposed in order to take the production up to 3,850 tU/yr. However, in April 2014 plant investment was put on hold for at least two years due to the low uranium price. Paladin has confirmed that it remains on track to meet production of 2,450-2,630 tonnes of uranium for 2015 (WNA, October 2014).

\section{Klein Trekkopje}

The Trekkopje uranium deposits are located about $80 \mathrm{~km}$ from Swakopmund (Fig. 2) and are hosted in the calcrete of two converging palaeo-channels. The project comprises two separate deposits, Trekkopje and the larger Klein Trekkopje, which is about $16 \mathrm{~km}$ long and 1 to $3 \mathrm{~km}$ wide. Some of the information in the following section has been extracted from an SRK (Steffan, Robertson and Kirsten) project report (163701) supplied by Areva; the remainder is taken from the thesis of Youlton (2007). The sediments are highly variable with alternating layers, predominantly conglomeratic $(\sim 80 \%)$, with minor lenses of sands $(\sim 10 \%)$ and clays $(\sim 5 \%)$, interspersed with rare boulders and cobbles $(<5 \%)$. This variable lithology reflects rapid changes in water velocity. The sediments are poorly consolidated, ranging from friable in the upper zones, to massive and weakly lithified at depth. According to the Areva report, cementation of the clastic material began at some time in the mid-Tertiary, and continued in intermittent stages, with deposition of calcite, plus minor dolomite, celestite, and barite. In the cementation process, calcite crystallisation increased permeability of the horizon by wedging clasts apart to form voids and fracture sites that were favourable for the precipitation of later uranium mineralisation.

Calcrete horizons at 1-2 $\mathrm{m}$ (occasionally close to $7 \mathrm{~m}$ ) persist to a depth of $20 \mathrm{~m}$ and occasionally to $30 \mathrm{~m}$. The bedrock to the palaeochannels comprises coarse-grained marble, biotite schist, leucogranite or dolerite. The schists contain $>110 \mathrm{ppm}$ vanadium and are likely to be the source of the vanadium required for carnotite formation (Youlton, 2007). The leucogranites (which range from syenogranite to granodiorite in composition) are the tourmaline-bearing Type B granites of Nex (1997) and contain <5 ppm uranium, so it is unlikely that these are the main uranium source. It is more likely that migrating groundwater derived uranium from Mesozoic Spitzkoppe alkaline granites to the east of the deposit and vanadium from schists in the bedrock of the palaeo-channels (Youlton, 2007).

Carnotite, forms bright yellow, visible disseminations and coatings in the matrix of calcrete-cemented conglomerate. There are two types of carnotite: Type 1, which is dominant and consists of disseminations of carnotite aggregates interstitial to conglomerate clasts in the matrix and is common in the more porous and permeable portions of partially calcium carbonate cemented conglomerate, as well as being attached to fine clay particles. Type 2 mineralisation consists of carnotite that is internal to calcium carbonate cement in the matrix of the conglomerate (Youlton, 2007). Highest ore grades occur where the two channels converge. The gangue, which consists of quartz, feldspar, mica, palygorskite, smectite and calcite, forms about $17 \%$ of the assemblage with carnotite showing a strong association with palygorskite and minor montmorillonite. Several parameters that might be expected to have controlled ore deposition are constant across both mineralised and unmineralised areas. For example, the redox potential, a parameter that is important in maintaining vanadium in the most favourable oxidation state for carnotite formation, doesn't change from a less oxidising environment to a more oxidising one as might be expected if Eh were controlling mineralisation. Similarly, the $\mathrm{pH}$ is maintained very close to 7 by a carbonate buffer, in both mineralised and unmineralised areas. What does differ is that the water table level is higher "upstream" of the deposit than "downstream", suggesting that where evaporation rates are greater closer to the surface, the higher evaporation induced uranium deposition. Water "downstream" of the deposit contained lower levels of dissolved uranium ions than the water "upstream", suggesting that uranium deposition continues to the present day (Youlton, 2007). In contrast, in a company report, it is stated that the dating of the Trekkopje deposits indicates an age of 2 to $5 \mathrm{Ma}$ for the most recent mobilisation of uranium mineralisation, although the source of this data and the technique used are not described.

The US $\$ 1$ billion project developed by Areva Resources Namibia, was based on shallow open-pit mining of the deposit where $80 \%$ of the ore is less than $15 \mathrm{~m}$ deep, with a shallow, high-tonnage lowgrade deposit (0.012-0.015\%) covering an area of about $16 \times 4 \mathrm{~km}$ in extent. Heap leaching with a sodium carbonate/bicarbonate process would be followed with the spent waste being back-filled into the original channel. In 2008, Areva quoted 45,600 tU resources, but then revised this to 26,000 $\mathrm{tU}$ in 2011 at lower grades (WNA, March 2015). Over 9,000 tonnes of vanadium pentoxide was also envisaged as a by-product. At the end of March 2009, the first production of a sodium diuranate bulk sample of 80,000 tonnes was produced from the mini pilot plant. The mine was intended to produce 3,200 tU/yr from 2013, with water supplied from a coastal desalination plant set up by Areva (Table 6) (WNA, March 2015). Production from a smallscale pilot plant in 2012-13 was $437 \mathrm{tU}$ (Table 7), demonstrating the 
feasibility of the project, but development stalled and the project has been put onto care and maintenance due to both the continued decrease of uranium prices and the required investments still to be made on site (WNA, March 2015).

\section{Marenica}

For the Marenica prospect, $30 \mathrm{~km}$ north of Trekkopje, Marenica Energy in 2010 announced an Indicated Resource of 2,500 tU at $0.01 \%$ $\mathrm{U}$, and an Inferred Resource of $19,600 \mathrm{tU}$ in $0.008 \% \mathrm{U}$ ore (Table 6), mostly in a palaeo-channel but with some granite-alaskite basement rock down to $60 \mathrm{~m}$ (WNA, March 2015).

\section{Tubas-Tumas}

This palaeochannel project covers extensive secondary calcrete deposits with a 2,350 tU inferred resource for Tubas calcrete and 4,470 tU indicated for Tumas (25 km southeast of Tubas), both at $0.03 \%$ U (WNA, March 2015). The Aussinanis project, also a palaeochannel deposit, near the coast, has 6,976 tU indicated and inferred resources at about $0.02 \% \mathrm{U}$ (Table 6) (WNA, March 2015).

\section{Botswana}

Several sandstone-hosted roll-front/calcrete uranium deposits have been investigated in Botswana. The Letlhakane project in the northeast of the country, was the first to publish a JORC-compliant indicated resource. The project covers a shallow deposit hosted in flat-lying Permian to Jurassic sandstones, to a depth of 75 m over a 9 $\mathrm{km}$ length and is open to the west. It comprises the Serule prospect in the south and Gojwane in the north as well as the Gorgon, Gorgon South, Mokobaesi, and Kraken prospects (WNA, March 2015). Some uranium occurs at roll-front redox boundaries, with subsequent reprecipitation into narrow, high grade $\left(<1,500 \mathrm{ppm} \mathrm{Uf} \mathrm{O}^{\wedge}\right)$ tabular zones of mineralisation in fine-grained sandstones, confined by mineralised (150-450 ppm Uf $\mathrm{O}^{\wedge}$ ) organic rich mudstones. Secondary uranium minerals in the near surface weathering environment resulted in uranium vanadates forming fine, yellow coatings on fracture surfaces and bedding planes. Supergene remobilisation and reprecipitation of uranium has also resulted in concentrations of calcrete-hosted carnotite which is amenable to alkaline or acid heap leaching. Production at about 1,350 tU/yr is envisaged, with export through Namibia. Resources totaling 61,000 tU at $0.015 \% \mathrm{U}$, includes $29,000 \mathrm{tU}$ at $0.013 \% \mathrm{U}$, a JORC-compliant indicated resource in the Gojwane deposit (WNA, March 2015). In July 2013 the Serule deposit was upgraded to $22,160 \mathrm{tU}$ at $0.017 \%$ $\mathrm{U}$ indicated and $96,750 \mathrm{tU}$ inferred at $0.018 \% \mathrm{U}$, all at $100 \mathrm{ppm}$ cut-off.

\section{Other areas}

In Morocco, exploration for uranium was undertaken by French and Russian geologists prior to 1982 and currently the government is encouraging exploration for uranium in palaeochannels in the Haute Moulouya, Wafagga and Sirwa areas. In Mauritania, exploration around Bir Moghrein and Ain Ben Tili by Forte Energy and Aura Energy, has shown uranium mineralisation associated with calcrete deposits.

\section{Quartz-pebble conglomerate reefs}

Quartz-pebble conglomerate deposits comprise well-rounded and well-sorted pebbles of quartz and minor chert in a pyrite-rich matrix. The major deposit of this type is the Witwatersrand Basin in South Africa, where gold abundance is greater than uranium, whereas in the Blind River-Elliot Lake deposit in Canada, uranium minerals are dominant with subordinate rare earth minerals.

\section{South Africa}

The Witwatersrand Basin (Fig. 15a) is an area $~ 330 \times 150 \mathrm{~km}$ in extent, lying south and southwest of Johannesburg with a thickness of 2,500-4,500 m of Witwatersrand Supergroup sediments comprising shale, sand and gravel, deposited 3.0 to 2.7 billion years ago Fig. 15b). The Dominion Group lies unconformably on a granitegreenstone basement and underlies the Witwatersrand Supergroup. Gold and uraninite particles, plus rounded pebbles of pyrite and other heavy minerals are preserved in thin quartz pebble beds, termed 'reefs', that individually extend for several kilometres. These reefs are interbedded with quartzites and minor argillites in the Witwatersrand Supergroup. The quartz-pebble beds occur in several stratigraphic cycles in six fluvial fans on the north and west sides of the Basin.

In spite of being mined since 1886 , there is no consensus of opinion as to the timing and mechanism of gold and uranium mineralisation. A modified placer model envisages that detrital gold and uraninite grains were derived from granite-greenstone terranes and deposited close to shore line in an anoxic Archaean atmosphere, during sedimentation in the basin, with subsequent remobilisation and redistribution by hydrothermal fluids during burial metamorphism. These hydrothermal fluids carried a primitive hydrocarbon oil, which, when it encountered uranium-bearing minerals, was transformed into bitumen. Evidence cited includes rolled and flattened gold particles and fluid inclusion data (Kirk et al., 2002; Frimmel et al., 2006). In contrast, the hydrothermal model envisages that gold and uranium were introduced by hot fluids, during or after regional metamorphism to lower greenschist facies, with delicate crystals and dendritic gold being amongst the cited evidence (Barnicoat et al., 1997; Phillips et al., 2012) More recently, Heinrich (2015) suggests that acid rain derived from sulphurous volcanic eruptions could have dissolved and transported gold and presumably uranium into the Witwatersrand Basin with precipitation promoted by fluid interaction with the organic material in shallow lakes and pools.

In addition to the quartz pebbles in the beds, the mineralogy is characterised by minor to trace amounts of pyrophyllite, sericite and chlorite (Phillips and Law, 1994), together with sulphides dominated by pyrite with traces of pyrrhotite, chalcopyrite, gersdorffite, cobaltite, chromite, sphalerite and galena (Robb and Meyer, 1995). In reefs with carbonaceous matter (Carbon Leader, Dominion and Vaal Reefs), the highest gold and uranium concentrations occur in zones rich in pyrobitumen (Mossman et al., 2008). QEMSCAN studies (Fig. 15c and d) show that major uranium minerals are uraninite, secondary coffinite, brannerite, minor uranothorite and uranium-bearing leucoxene (titanium oxide of earthy habit), with grain sizes ranging from 30-350 $\mu \mathrm{m}$ and an average size of $70 \mu \mathrm{m}$ (Kinnaird et al., 2011).

Detrital rounded uraninites may be partially replaced by bitumen with rims of gold and pyrrhotite, while later uraninites host inclusions 


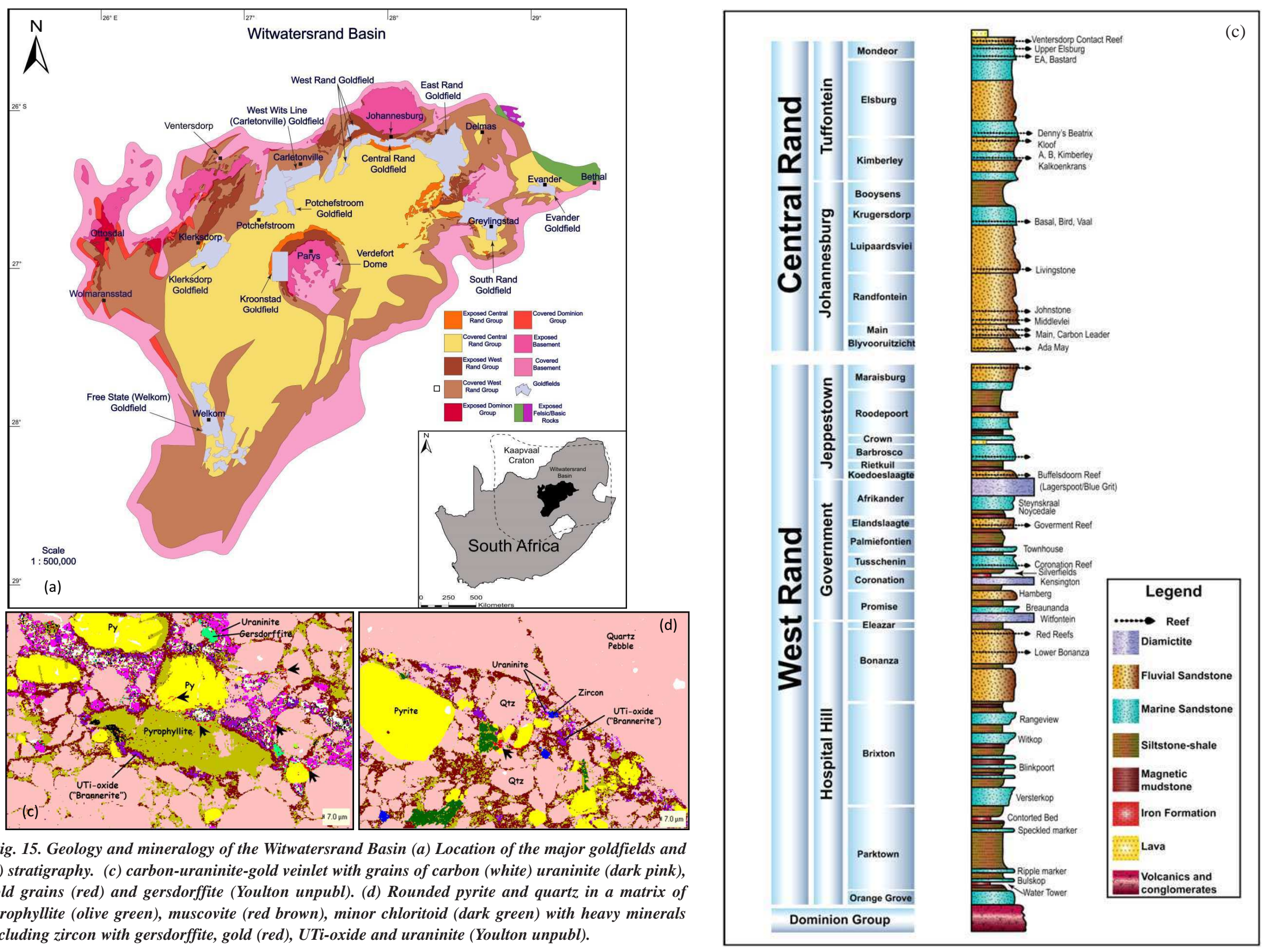


of gold, pyrrhotite, pyrite, chalcopyrite, quartz, or phyllosilicates. Carbon-uraninite-gold veinlets may be associated with relatively coarse gersdorffite, and brannerite is abundant (Kinnaird et al., 2011).

The majority of past production was as a by-product of gold, with only two primary uranium producers, the Beisa mine in the Free State (in the early 1980s) and the Dominion Reefs Uranium Mine near Klerksdorp (NEA, 2014). The surge in the uranium price between 2005 and 2007 led to significant interest, especially in the resources of the extensive tailings created over 120 years of mining.

Within the basal Dominion Group west of Klerksdorp, two uraniferous reefs occur in the quartz-pebble conglomerates separated by $18 \mathrm{~m}$ of quartzite (von Backstrom, 1975). The Upper Reef is the most uranium-enriched with grades of up to $1 \% \mathrm{U}$ over $0.5 \mathrm{~m}$ at the top of the thick conglomerate (von Backstrom, 1975). Uraninite is partially replaced by coffinite and uraniferous leucoxene. Low gold grades of 2-3 ppm in the Upper Reef results in limited uranium production, however 1,931 tU were mined from the Dominion Reef and Rietkuil Mines west of Klerksdorp between 1955 and 1963 (Antrobus et al., 1986). In early 2007, processing of underground uranium ore resumed at the Dominion Mine with a planned output of $1,900 \mathrm{tU}_{3} \mathrm{O}_{8}$ per year by 2011 . However, the mine only produced 85 $\mathrm{tU}_{3} \mathrm{O}_{8}$ in 2007, 300 tonnes in 2008 and operations ceased due to higher than expected production costs and low uranium prices. Dominion had indicated resources of $55,000 \mathrm{tU}_{3} \mathrm{O}_{8}$ at $0.062 \%$ and inferred resources of $62,800 \mathrm{tU}_{3} \mathrm{O}_{8}$ at $0.036 \%$. The mine was closed in October 2008, then sold in April 2010 to Shiva Uranium, which resumed uranium production early in 2011 . No production information is available on the company website.

The West Rand Group of the Witwatersrand Supergroup is relatively depleted in uranium although it has been exploited from the Jeppestown sub-group west of Klerksdorp, on and around the farm Rietkuil. Distribution here and in the overlying Government Reef of the Government sub-Group is patchy, probably as a result of an infertile source area, with brannerite reported as the most abundant uranium phase (Saager et al., 1982). Production of $305 \mathrm{tU}$ was reported for the West Rand Group (Ford, 1993). The Central Rand Group is host to several quartz-pebble reefs with uranium grade increasing from $\sim 50 \mathrm{ppm}$ in the Evander goldfield southwards towards Welkom, where grades are several hundred ppm (Cole, 1998). While these rocks represent a major uranium resource, the economics of mining and processing are largely controlled by the associated gold grades and one of the major advantages of uranium leaching is that it results in improved gold recoveries (Lottering et al., 2008). Where uranium is recovered as a by-product of gold mining, the grade may be as low as $0.01 \%$. Since uranium is not recovered during processing of brannerite, any new projects may encounter low uranium recovery from ores if this is not taken into account.

The two main producers of uranium in the Witwatersrand Basin are the Vaal River and Ezulwini mines. The AngloGold Ashanti Vaal River mine near Klerksdorp is the dominant producer. It has three mines producing uranium as a by-product to gold from the Vaal Reef and more recently the Crystalkop Reef at the Great Noligwa, Kopanang, and Moab Khotsong mines. In 2009, AngloGold began construction of a new uranium recovery plant at its Kopanang mine. Production in 2011 was $800 \mathrm{tU}_{3} \mathrm{O}_{8}, \sim 600 \mathrm{tU}$ in 2012 and $532 \mathrm{tU}$ in 2013 (WNA, March 2015).

The Ezulwini/Cooke operations on the outskirts of Westonaria, $40 \mathrm{~km}$ southwest of Johannesburg, have produced over 6,000 tU from the 1960s to 2001. After extensive investment, uranium production resumed in 2009 and the project had 3,200 tU in measured and indicated resources and 85,000 tU inferred resources from underground and from mine-waste tailings (WNA, March 2015). A seven-year ramp-up of underground production from the Middle Elsburg reef was planned, but the plant was placed on care and maintenance in February 2012 with production that year of only 34 tU (WNA, March 2015). Gold One International acquired the operation in 2012 but Sibanye Gold took over operations and produced 10 tonnes ammonium diuranate in early 2014, with plans of ramping this up to $230 \mathrm{tU} / \mathrm{yr}$ by 2016.

A number of other potential uranium producers on the goldfield have quoted resources, but production may be dependent on the uranium price. The Beatrix West Section - previously Oryx - has indicated and inferred uranium resources on the Beisa Reef of 9,900 $\mathrm{tU}$ at $0.079 \% \mathrm{U}$ (Sibanye, 2013). At Randfontein, $10 \mathrm{~km}$ southwest of Krugersdorp, Rand Uranium has resources of 41,000 tU, both in tailings and the underground mine. Dominion, including the Rietkuil section, has indicated resources of $51,000 \mathrm{tU}_{3} \mathrm{O}_{8}$ at $0.063 \%$ and inferred resources of $62,800 \mathrm{tU}_{3} \mathrm{O}_{8}$ at $0.036 \%$. Significant investment has been made in processing plants to extract uranium from waste from historical gold mining, stored in old ore dumps and tailings dams, through a Mine Waste Solutions project and these represent a significant resource for the future.

\section{Shale-hosted deposits}

\section{Zambia}

In the $300 \mathrm{~km}$ long Lufilian arc, uranium mineralisation occurs in association with copper, cobalt and nickel in the Ore Shale. Denison Mines of Canada plans to develop the two shallow ore bodies of Mutanga and Dibwe in the Mutanga uranium project in southern Zambia, when uranium prices improve beyond US\$ $65 / \mathrm{lb}$. Measured resources for the Mutanga project in September 2013 are $770 \mathrm{tU}$ at $0.04 \% \mathrm{U}$, indicated resources are 2,235 $\mathrm{tU}$ and inferred resources $16,000 \mathrm{tU}$ plus an inferred resource of 10,870 tU for the Dibwe East project, between the other two (WNA, March 2015).

The Lumwana mine in northwest Zambia (Figs. 10 and 16), although primarily a copper deposit, has a uranium resource of $3,800 \mathrm{tU}$ indicated resources at $0.079 \% \mathrm{U}$ and $2,570 \mathrm{tU}$ in inferred resources (WNA, March 2015). In the Malundwe pit, uraninite occurs in high-grade veins primarily within two discrete zones in the hanging wall and footwall to the copper mineralisation. Uranium is mined separately from copper ore and stockpiled and treatment of the uranium ore to produce $700 \mathrm{tU} / \mathrm{yr}$ was planned from 2010. However, investment in the US\$2 30 million uranium mill was deferred due to low prices. In January 2011 Barrick reported 4.6 Mt stockpiled uranium ore containing $0.09 \% \mathrm{U}$ and $0.8 \% \mathrm{Cu}$ but in late 2014 it was decided to suspend operations at Lumwana after the Zambian government increased mining royalties from $6 \%$ to $20 \%$.

\section{Vein-style deposits}

\section{$D R C$}

Shinkolobwe Mine near Likasi, was discovered in 1915 and initially mined for radium in an open pit, to a depth of $57 \mathrm{~m}$ between 1921 and 1936 and from underground workings (Derricks and Vaes, 1955). The Shinkolobwe Mine is one of the world's best known 


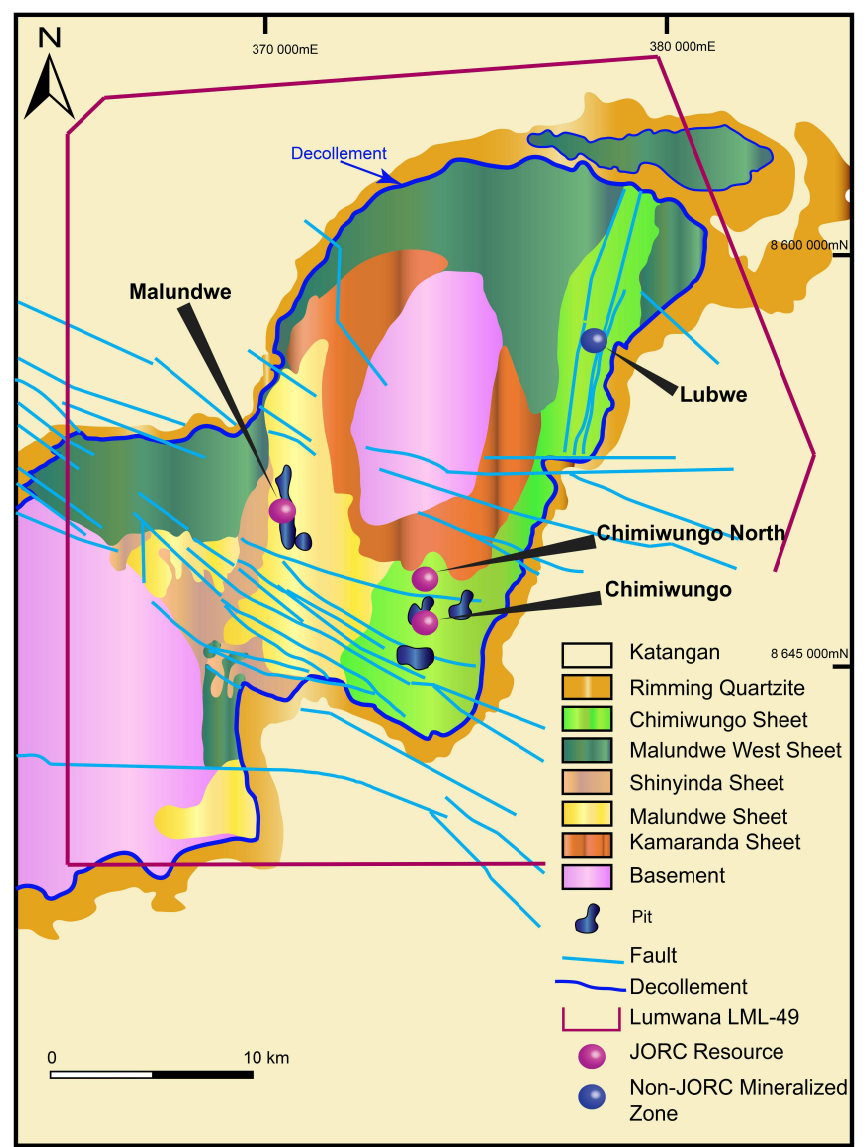

Fig. 16. Geological map showing the location of the two open pits Chimiwungo and Malundwe on the edge of the Mwombezhi Dome.

sources for radioactive minerals and is the type locality for 34 minerals, most of them being radioactive minerals. The deposit comprises a stockwork of veins hosted in siliceous dolomites and dolomitic or carbonaceous shales of the Roches Siliceuses Feuille (RSF) and Roches Siliceuse Cellulaire (RSC) units of the Mines Series of the Katangan Group in the DRC Copperbelt, (Derricks and Oosterbosch, 1958) within an overturned block. The veins are on the flank of a vertical breccia with clasts of copper-cobalt rich Mines Series and mineralisation extends along faults and veins out into the surrounding host rocks with some uranium minerals specific to certain host rock types (Derricks and Vaes, 1955). Early veins of magnesite were followed by stockwork veinlets with or without dolomite or magnesite, comprised of uraninite surrounded by gummite, sklodowskite and torbernite associated with cobalt and nickel minerals, whereas secondary minerals such as kasolite appear to be restricted to sedimentary hosts (Derricks and Vaes, 1955). The uraninite is characterised by traces of gold and palladium. At depth beneath a dome of "roches argileuses talqueuses" (RAT), abundant fissures host uraninite, pyrite, molybdenite, selenium sulphide, monazite and traces of copper minerals. Grades of uraninite were between 0.1 and $0.2 \%$ (Derricks and Oosterbosch, 1958). U-Pb dating on the veins gives an age of $652.3 \pm 7.3 \mathrm{Ma}$ (Decree et al., 2011). Above a depth of $57 \mathrm{~m}$ there is an oxidised zone with abundant secondary minerals which rapidly diminish in abundance below this depth (Derricks and Vaes, 1955). Similar vein hosted uranium mineralisation occurs at Swambo and Kalongwe (Derricks and Oosterbosch, 1958).

\section{Unconformity-related deposits}

Uranium mineralisation at Tahaggart in Algeria, occurs in a minor unconformity-style deposit which was discovered in the 1970s. It occurs irregularly at the contact between the crystalline Eburnean basement and the overlying Cambro-Ordovician sediments as fine lamellae, pods and disseminations of secondary autunite, torbernite and carnotite in sandstone cement and in veins. Several mineralised bodies extend in a northwesterly direction, with a dip to the southwest and vary in thickness from 1 to $8 \mathrm{~m}$. Uranium grades decrease downdip. Resources are reported as 26,000 tU and no production has been reported.

The Majete project in southern Malawi, investigated by African Energy, straddles the faulted contact between older uranium-enriched basement rocks and younger rocks. A small uranium occurrence in the basement rocks is noted on regional geological maps and airborne radiometric surveys, suggesting that the basement may provide a good source of uranium to be remobilised into the nearby Upper Karoo sediments.

\section{Other styles of deposit}

\section{Uranium-bearing phosphates}

In Morocco, feasibility of uranium recovery from the 27 million tonnes of phosphate mined for fertilizer has been considered but the economics of the extraction process for low-grade ore (mostly $<200$ ppm U), has hampered the development of uranium extraction from the phosphate to date. In the Central African Republic, large very high-grade deposits of uranium-bearing phosphatic sediments were discovered in 1959-1961 near Bakouma in the east of the country. Further feasibility studies showed that there are 20,000 tonnes $\mathrm{U}_{3} \mathrm{O}_{8}$ averaging $0.27 \%$ in ten separate areas. Layered clay-rich and phosphatic sediments occur within depressions thought to be karstic features within a broad drainage area. The uranium is hosted preferentially within the phosphatic layers in a very large variety of mineral forms with autunite being the most common. Inferred resources of $36,475 \mathrm{tU}$ at $0.02 \%$ were reported at the end of 2013 (www.wise-uranium). Following a feasibility study in 2010, Areva planned to develop the project using open pit mining at 1,200 tU/yr, ramping to full production in 2014-15, however production has been delayed due to low uranium prices and the ongoing political situation within the country. Other uranium occurrences are known in phosphorites on the continental shelf off the western and southern coasts of South Africa (Cole, 1998).

\section{Aeolian Deposits}

In Namibia, Deep Yellow/Reptile's shallow aeolian Tubas Red Sand deposit $10 \mathrm{~km}$ south of Inca and $70 \mathrm{~km}$ southwest of Swakopmund, has indicated and inferred resources of 10,900 tU at $0.0125 \% \mathrm{U}$ as carnotite.

\section{Coal and shale}

The Springbok Flats project in South Africa is owned and has been drilled by the Holgoun Group. They have a SAMREC compliant resource of 100,000 tonnes $\mathrm{U}_{3} \mathrm{O}_{8}$ associated with Karoo coal. They envisage a production capacity of 900 tonnes $\mathrm{U}_{3} \mathrm{O}_{8}$ per year (Holgoun website). 


\section{Lacustrine deposits}

Some relatively small deposits are hosted within inland basins where outward drainage is lacking. The Henkries uranium project in the Northern Cape Province of South Africa, $80 \mathrm{~km}$ north-northeast of the town of Springbok, hosts uraninite and urano-organic complexes in a Neogene-aged buried lake. The deposit is bound on its northern end by a rocky constriction of the drainage. Mineralisation occurs in a $5.8 \mathrm{~m}$ thick, soft peat-like organic-rich layer overlain by whitish diatomite, alluvium, calcrete and aeolian sand and has a grade of $\sim 570 \mathrm{ppm}$. The deposit was discovered by Anglo American in the 1970s. A Measured and Indicated resource of 1.35 million tonnes grading at 501 ppm $\mathrm{U}_{3} \mathrm{O}_{8}$ was defined by Niger Uranium in 2009.

\section{Concluding remarks}

It is clear that Africa is host to a large variety of styles of uranium deposits and that considerable resources remain, including reprocessing of waste material from gold mining. Economic viability however, is driven by world demand and price, and political stability of the African countries in which the deposits are hosted. Many projects that were explored in the period 2006-2009 will become viable again only when the uranium price rises.

\section{Acknowledgements}

The authors are grateful to Guy Freemantle for help with several of the diagrams and to Brain Hambleton Jones and Andrew Pedley for helpful reviews. The NRF-DST Centre of Excellence, CIMERA, is acknowledged for financial support.

\section{References}

Antrobus, E.S.A., Brink, W.C., Brink, M.C., Caulkin, J. Hutchinson, R.I., Thomas, D.E. van Graan, J.J. and Viljoen. 1986. The Klerksdorp Goldfield. In: Mineral deposits of Southern Africa. Eds: C.R. Anhaeusser, and S. Maske. Geological Society of South Africa 698-703.

Barnicoat, A. C. Henderson, I.H.C. Knipe, R.J. Yardley, B.W.D. Napier, R.W. Fox, N.P.C., Kenyon, A.K., Muntingh, D.J., Strydom, D., Winkler, S., Lawrence, S.R. and Cornford C. 1997. Hydrothermal gold mineralization in the Witwatersrand basin. Nature, 386, 820-824.

Basson, I.J. and Greenway, G. 2004. The Rössing uranium deposit: a product of late-kinematic localization of uraniferous granites in the Central Zone of the Damara Orogen, Namibia. Journal of African Earth Sciences, p. 38 413-435.

Bigotte G. and Molinas E. 1973. How French Geologists discovered Niger uranium deposits. World Mining (April 1973) pp. 34-9.

Bigotte G. and Obellianne J.M. 1968. Découverte de minéralisations uranifères au Niger. Mineralium Deposita 3, 317-33.

Bowden, P., Bennett, J.N., Kinnaird, J.A., Whitley, J.E., Abaa, S.I. and Hadzigeorgiou-Stavrakis, P.K. 1981. Uranium in the NigerNigeria younger granite province. Mineralogical Magazine 44: 379-389.

Bowden, R.A. Shaw, R.P. 2007. The Kayelekera uranium deposit, Northern Malawi: past exploration activities, economic geology and decay series disequilibrium. Applied Earth Science (Trans, Inst. Min. Metall. B), 116, 55-67.

Briqueu, L., Lancelot, J.R., Valois, J-P., and Walgenwitz, F. 1980. Géochronologie $\mathrm{U}-\mathrm{Pb}$ et genèse d'un type de mineralisation uranifère. Les alaskites de Goanikontès (Namibie) et leur encaissant. Bulletin Centres Recherches Exploration Production Elf, Aquitaine, 4, 759-811.

Brunnschweiler, R.O. 1974. New K-Ar Age determinations from the West African Shield in the Niger Republic . Geology, 2, 17-20.

Cazoulat, M. 1985. Geologic environment of the uranium deposits in the Carboniferous and Jurassic sandstones of the western margin of the Air Mountains in the Republic of Niger: Vienna, International Atomic Energy Agency, Geological environments of sandstone-type uranium deposits, Tecdoc-328, p. 247-603.

Cole, D.J., Labuschagne, L.S. and Sohnge, A.P.G. 1991. Aeroradiometric survey for uranium and ground follow-up in the main Karoo Basin. Memoir, Geological Survey of South Africa $76,145 \mathrm{pp}$.

Cole, D. 1998. Uranium. In: The Mineral Resources of South Africa. (Wilson, M.G.C. and Anhaeusser, C.R., eds). Handbook, Council for Geoscience, 16, 642-658.

Corner, B. 1983. An interpretation of the aeromagnetic data covering the western portion of the Damara Orogen in South West Africa/ Namibia. In: Miller, R.McG. (Ed.), Evolution of the Damara Orogen of South West Africa. Namibia: Geological Society of South Africa, Special Publication, 11, pp. 339-354.

Dahlkamp, F.J. 1993. Uranium ore deposits: Berlin, Springer-Verlag, 460 pp.

Decrée, S., Deloule, E., De Putter, T., Dewaele, S., Mees, F., Yans., J., Marignac, C., 2011. SIMS U-Pb dating of uranium mineralization in the Katanga Copperbelt: Constraints for the geodynamic context. Ore Geology Reviews, 40,81-89.

Derricks, J. J. and Vaes, J.F. 1955. The Shinkolobwe uranium deposit: current status of our geological and metallogenic knowledge. Peaceful Uses of Atomic Energy, Geneva, United Nations.

Derricks, J. J. and Oosterbosch, R. 1958. The Swambo and Kalongwe deposits compared to Shinkolobwe: contribution to the study of Katanga Uranium. Proceedings of the 2nd International conference on the peaceful uses of Atomic Energy.

Eberle, D., Andritzky, G. and Wackerle, R. 1995. The new magnetic data set of Namibia: Its contributions to the understanding of crustal evolution and regional distribution of mineralization. Communications of the Geological Survey of Namibia. 10: 141150.

Fleurance' S., Cuney, M. and Kinnaird, J.A. 2011. Mineralogical, Geochemical and isotopic study of 6 samples from the Langer Heinrich calcrete deposit (Namibia). Internal report to Langer Heinrich Mine.

Ford, M.A. 1993. Uranium in South Africa. Journal of the Institute for Mining and Metalogeny, 93, 37-58.

Frimmel, H. E., Groves, D.I., Kirk, J., Ruis, J., Chesley, J. and Minter, W.E.L. 2005. In Economic Geology $100^{\text {th }}$ Anniversary Volume (eds. Hedenquist, J.W., Thompson, J. F. H., Goldfarb, R. J. \& Richards, J. P.) 769-797 (Society of Economic Geologists, 2005).

Freemantle, G.G. 2015. Primary Uranium Mineralisation of the Central Damara Orogen, Namibia. PhD thesis, University of the Witwatersrand, South Africa.

Freemantle, G.G. 2015. Primary Uranium Mineralisation of the Central Damara Orogen, Namibia. PhD thesis, University of the Witwatersrand, South Africa.

Gray, T. 2015. The Geological Setting of Uranium Mineralisation in the Rössing Area, Namibia. PhD thesis, University of the Witwatersrand, South Africa 198 pp.

Guy, B., Beukes, N.J. and Gutzmer, J. 2010. Palaeoenvironmental controls on the texture and chemical composition of pyrite from non-conglomeratic sedimentary rocks of the Mesoarchaean Witwatersrand Supergroup, South Africa. South African Journal of Geology, 113: 2 195-228. 
Hambleton-Jones, B.B. and Toens, P.D. 1978. The geology and geochemistry of calcrete/gypcrete uranium deposits in duricrust: Namib Desert, South West Africa. Economic Geology, 73, 14071408.

Herd, D.A., 1996. Geochemistry And Mineralisation Of Alaskite In Selected Areas Of The Rössing Uranium Mine, Namibia. Unpublished MSc. Thesis, University of St. Andrews.

IAEA, 2009. World distribution of uranium deposits (UDEPO) with uranium deposit classification. 2009 edition. IAEA-TECDOC1629. ISBN 978-92-0-110509-7, Vienna.

Iilende, 2012. The source of uranium and vanadium at the Langer Heinrich and Klein Trekkopje uranium deposits - genesis and controlling factors. MSc thesis, University of Namibia. 266 pp.

Jacob, R.E. 1974. Geology and Metamorphic Petrology of part of the Damara orogen along the Lower Swakop River, South West Africa. Cape Town.

Jacob, R.E., Corner, B. and Brynard, H.J. 1986. The regional and structural setting of the uraniferous granite provinces of southern Africa. In "Mineral deposits of southern Africa". Eds., C.R. Anhaeusser and S. Maske. 2: 1807-1818. Geological Society of South Africa, Johannesburg.

Kinnaird, J.A. and Nex, P.A.M., 2007. A review of geological controls on uranium mineralisation in sheeted leucogranites within the Damara Orogen, Namibia. Applied Earth Science, Transactions of the Institute of mining and Metallurgy 116, 68-85.

Kinnaird, J.A., Nex, P.A.M. and Freemantle G. 2009. Uranium deposits in Central Namibia. Uranium field guide $22^{\text {nd }}-26^{\text {th }}$ June 2009.

Kinnaird, J.A. Youlton, B., Theron, S., Martin G., Freemantle, G. and Nex, P. 2011. Geometallurgy of two major uranium deposit types. $23^{\text {rd }}$ Colloquium of African Geology, University of Johannesburg, South Africa, January $8^{\text {th }}-14^{\text {th }} 2011$.

Kirk, J., Ruiz, J., Chesley, J.,Walshe, J. and England, G. 2002. A major Archean, gold and crust-forming event in the Kaapvaal Craton, South Africa. Science 297, 1856-1858.

Kröner, A., Retief, E.A., Compston, W., Jacob, R.E. and Burger, A.J., 1991. Single grain and conventional zircon dating of remobilised basement gneisses in the central Damara belt of Namibia. South African Journal of Geology, 94, 379-387.

Le Roux, J.P. 1993. Genesis of stratiform U-Mo deposits in the Karoo Basin of South Africa. Ore Geology Reviews, 7, 485509

Longridge, L. 2012. Tectonothermal evolution of the southwestern Central Zone, Damara Belt, Namibia. Unpublished PhD thesis, University of the Witwatersrand.

Lottering, M.J., Lorenzen, L., Phala, N.S., Smit, J.T. and Schalkwyk, G.A.C. 2008. Mineralogy and uranium leaching response of low grade South African ores. Minerals Engineering 21, 16-22.

Marlow, A.G.M. 1981. Remobilisation and primary uranium genesis in the Damaran Orogenic Belt. PhD thesis, University of Leeds, pp247.

Marlow, A.G. 1983. Geology and geochronology of mineralised and anomalous granites and alaskites, Namibia. Geological Society of South Africa Special Publication, 11, 289-298.

McCarthy, T.S. 2006. The Witwatersrand Supergroup. In: Johnson, M.R., Anhaeusser, C.R. and Thomas, R.J., (Eds.), The Geology of South Africa. Geological Society of South Africa, Johannesburg. Council for Geoscience, Pretoria, pp. 155-186.

Meshik, A.P. 2005. The Workings of an Ancient Nuclear Reactor. Scientific American, November 2005.

Miller, R. McG. 2008. The geology of Namibia. Ministry of Mines and Energy, 3 volumes, Namibia.

Mossman, D.J., Minter, W.E.L., Dutkiewicz, A. Hallbauer, A.K., George, S.C., Hennigh, Q., Reimer, T.O. and Horscroft, F.D. 2008.
The indigenous origin of Witwatersrand "carbon". Precambr. Res. 164, 173-186 (2008).

Mouillac, J.L., Valois, J-P. and Walgenwitz, F., 1986. The Goanikontes uranium occurrence in South West Africa/Namibia. In: Anhaeusser, C.R., and Maske, S. (Eds.), Mineral Deposits of Southern Africa Geological Society of South Africa, Vol II, 18331843.

NEA.IAEA, 1994. Uranium - Resources, Production and Demand OECD, Paris $311 \mathrm{pp}$.

Nex, P.A.M. 1997. Tectono-metamorphic Setting and Evolution of Granitic Sheets in the Goanikontes Area, Namibia. Unpublished $\mathrm{PhD}$. Thesis, National University of Ireland, University College, Cork.

Nex, P.A.M., Kinnaird, J.A.,and Oliver, G.J.H. 2001a. Petrology, geochemistry and mineralisation of post-collisional magmatism in the southern Central Zone, Damaran Orogen, Namibia. Journal of African Earth Sciences, 33, 3-4, 481-502.

Nex, P. A. M., Kinnaird, J.A. and Oliver, G.J.H. 2001. Petrology, geochemistry and uranium mineralisation of post-collisional magmatism around Goanikontes, southern Central Zone, Damaran Orogen, Namibia. Journal of African Earth Sciences 33: 481502.

Nex, P.A.M., Herd, D. and Kinnaird, J.A. 2002. Fluid extraction from quartz in sheeted leucogranites as a monitor to styles of uranium mineralization: an example from the Rössing area, Namibia. Geochemistry: Exploration, Environment, Analysis. 2.

Nex, P.A.M. and Kinnaird, J.A. 1995. Granites and their mineralisation in the Swakop River area around Goanikontes, Namibia. Communications of the Geological Survey Namibia, $10,51-56$.

OECD 2009. Uranium 2009: Resources, Production and Demand. OECD Publishing. 3 August 2010. pp. 305.

Oliver, G.J.H. and Kinnaird, J.A. 1996. The Rössing-SJ Dome, Central Zone, Damara Belt, Namibia: an example of mid-crustal extensional ramping. Communications of the Geological Survey of Namibia, 11, 53-64.

Paladin 2015. Project update. Kyelekera 2015.

Palfi, A.G., Wartha, R., Niedermayr, G. and Jahn, S. 2001. Das Boltwoodite-vorkommen von Goanikontes in der Namib. In: Jahn, S., Medenbach, O., Niedermayr, G., Schneider, G. (Eds.) Namibia Zauberwelt edler stein und Kristalle. Reiner Bode, Borkum, Germany, 126-135.

Pedley, A. 2007. The Trekkopje Project. Conference abstract: Uranium Exploration and Exploitation in Africa. DPP Course Geological Society of South Africa.

Phillips, G.N. and Powell, R. 2012. Origin of Witwatersrand gold: A metamorphic devolatilisation hydrothermal replacement model. Appl. Earth Sci.(Trans. Inst. Min. Metall. B) 120, 112-129.

Robb, L.J. and Meyer, F.M. 1995. The Witwatersrand Basin, South Africa: geological framework and mineralization processes. Ore Geology Reviews, 10, 67-94.

Saager, R., Utter, T. and Meyer, M. 1982. Pre-Witwatersrand and Witwatersrand conglomerates in South Africa: a mineralogical comparison and bearings on the genesis of gold-uranium placers - In Ore Genesis, the State of the Art, Amstutz, G. C., El Goresy, A., Frenzel, G., Kluth, C., Moh, G., Wauschkuhn, A. and Zimmermann, R. A. (eds). Berlin, Springer-Verlag, 38-56.

Spivey, M., Penkethman, A. and Culpan, N. 2010. Geology and mineralization of the recently discovered Rössing South uranium deposit, Namibia. Spec. Pub. Society of Economic Geologists, 15, 729-746.

Spurr, J.E. 1900. A reconnaissance in southwestern Alaska in 1898. Report of the United States Geological Survey. Washington. Pt.VII, p.31-264. 
Turner, B.R. 1985. Uranium mineralization in the Karoo Basin, South Africa. Economic Geology, 80, 256-269.

Turpina, L., Clauer, N., Forbes, P. and Pagel, M. 1991. U-Pb, Sm-Nd and K-Ar systematics of the Akouta uranium deposit, Niger. Chemical Geology, 87, 3-4, 217-230.

Venter, R. and Boylett, M. 2009. The evaluation of various oxidants used in acid leaching of uranium. Hydrometallurgy Conference 2009, The Southern African Institute of Mining and Metallurgy, 2009.

von Backstrom, J.W. 1970. The Rössing uranium deposit near Swakopmund, South West Africa. A preliminary report, Uranium Exploration Geology. IAEA Report IAEA -PL-391/12 Vienna, 143-150.

von Backstrom, J.W. 1975. Uranium and the generation of power, a South African perspective. Transactions, Geological Society South Africa, 78, 275-292.

Ward, J.D., Seely, M.K. and Lancaster, N. 1983. On the antiquity of the Namib. South African Journal of Science, 79, 175-183.

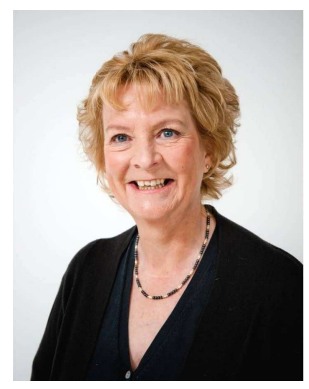

Judith Kinnaird is an Associate Professor of Economic Geology in the School of Geosciences, Director of the Economic Geology Research Institute at the University of the Witwatersrand and co-Director of CIMERA, a South African national centre of excellence for the study of minerals and energy. She gained an Honours BSc degree from the University of London, and an MSc and PhD from the University of St. Andrews in Scotland for research on tin-tungsten and columbite-bearing granites in ring complexes in Nigeria. She has worked on uranium deposits in Namibia, platinum and chromium in the Bushveld Complex, especially on the Platreef and Waterberg deposits and supervises research on central African copper mineralisation.
World Nuclear Association (WNA) October 2014. Uranium in Niger. www.wise-uranium.org (March 2015).

World Nuclear Association (WNA) March 2015. Uranium in Namibia. www.world-nuclear.org/info/country.

World Nuclear Association (WNA) September 2015. Uranium in Namibia. www.world-nuclear.org/info/country

Whiteside, H.C.M. 1970. Uraniferous Precambrain conglomerates of South Africa. In: Uranium Exploration Geology, International Atomic Press Agency, Vienna. 49-75

Youlton, B. 2007. Controls on Uranium Mineralization at the Klein Trekkopje Prospect, Namibia. BSc Honours thesis, University of the Witwatersrand, $63 \mathrm{pp}$.

Youlton, B. 2014. The Process Mineralogy of Selected Southern African Uranium Ores. Unpublished $\mathrm{PhD}$ thesis, University of the Witwatersrand $370 \mathrm{pp}$.

Youlton, B. and Kinnaird, J.A. 2013. Gangue-reagent interactions during acid leaching of uranium. Minerals Engineering 52, 6273.

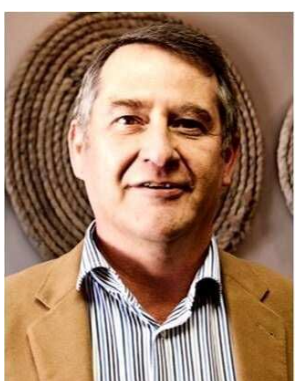

Paul Nex obtained a first-class BSc (Honours) degree in Earth Science from Oxford Brookes University in 1991 and a $P h D$ for his research on uranium mineralisation in sheeted leucogranites in Namibia from the National University of Ireland in 1997. His current research interests are in critical metals, particularly antimony and rare earth elements, uranium mineralisation in Namibia and mineralisation in the Bushveld Complex. 